\title{
Quality of Life in Children with Hearing Loss
}

Christiane Lingås Haukedal

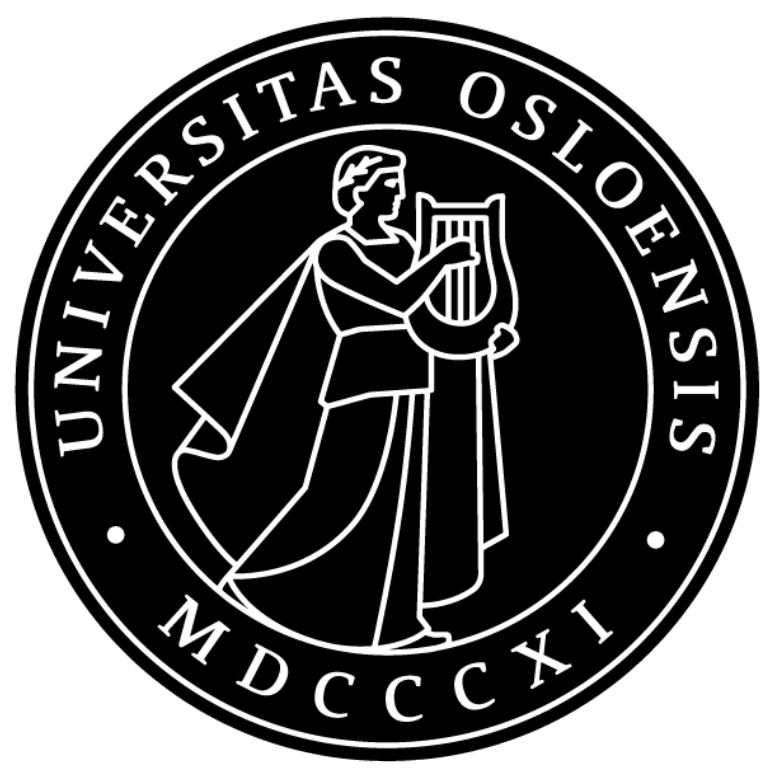

Department of Special Needs Education

UNIVERSITY OF OSLO 


\section{(C) Christiane Lingås Haukedal, 2020}

\section{Series of dissertations submitted to the}

Faculty of Educational Sciences, University of Oslo

No. 322

\section{ISSN 1501-8962}

All rights reserved. No part of this publication may be reproduced or transmitted, in any form or by any means, without permission.

Cover: Hanne Baadsgaard Utigard.

Print production: Reprosentralen, University of Oslo. 


\section{SKALA}

Det er grenser for hvor lykkelig man kan bli på en skala fra $1-10$.

(Larsen, 2005, p. 35) 


\begin{abstract}
The current thesis consists of three papers that, through examination of different samples and perspectives, aimed to evaluate health-related quality of life (HR-QOL) in children 5-12 years old with different degrees of bilateral hearing loss treated with an amplification device, but otherwise typical development. Their results were compared to peers with normal hearing. A second aim was to evaluate the association between language and communication and HR-QOL. Factors previously found to be associated with HR-QOL or psychosocial issues, such as age at implantation or diagnosis, nonverbal abilities and socioeconomic status, were examined in each paper

The results suggest that the majority of children and parents perceived the children's HR-QOL to be comparable to that of their peers with normal hearing. However, the children experienced significantly lower HR-QOL in some domains. Children using cochlear experienced lower QOL in domains related to social and school functioning compared with their peers. For children using hearing aids (HAs), school functioning was the only subdomain affected. Better spoken language skills or better communication skills, were found to be associated with higher HR-QOL. Factors such as age at implantation or diagnosis, nonverbal abilities and socioeconomic status were not found to be associated with HR-QOL.

Based on the findings in the current thesis, recommendations for future praxis are to use the advantages associated with early diagnosis to promote spoken language interventions in children with hearing loss. Improved spoken language skills seem not only to equip children to succeed academically but also to be an important tool for improving overall HRQOL. In addition, more knowledge is required to improve the follow up children receive in school, which should be the target in future studies in order to pinpoint which areas that need improvement. Combined, these strategies may be a step towards providing children with different degrees of hearing loss, educated in mainstream schools, with the same opportunities for well-being as their normal-hearing peers.
\end{abstract}




\section{Acknowledgements}

Først og fremst, tusen takk til deltakarane i prosjektet; foreldra og borna som har delt av sin kvardag. Det har gjort stort inntrykk på meg å møte dykk, og eg er svært takksam for at de har teke dykk tid. Eg håper denne avhandlinga kan bidra til å bringe nyansar inn i framtidige diskusjonar om habilitering, inkludering og tilrettelegging for born som har ulike grader av høyrselstap.

Eg vil så rette ei stor takk til rettleiarane mine. Tusen takk til Ona for at du introduserte meg for eit spanande fagfelt. Du har gitt meg rom til å vere kreativ i arbeidet med prosjektet, og spelt meg god. Du har alltid teke deg tid, og du har delt raust av din store faglege kunnskap og ditt engasjement for fagfeltet. Takk til Björn for gode faglege diskusjonar og utmerka rettleiing. Eg har sett stor pris på korleis dine innsiktsfulle kommentarar og spørsmål har ført arbeidet vidare. Takk og til mine medforfattar- takk til Janne for at du alltid har teke deg tid til spørsmål og diskusjonar, det har vore lærerikt og kjekt å jobbe saman. Takk til Stefan for tålmodig og kyndig statistisk opplæring, til Elizabeth for samarbeid om artiklar og for å ha teke meg så varmt i mot på forskingsopphald i Ottawa. Tida i lab'en i Ottawa var eit høgdepunkt i stipendiattida.

Stor takk til alle i CI-teamet og forskingsassistentane på Rikshospitalet for samarbeid om innsamling av data, faglege diskusjonar og innspel i doktorgraden. Eg vil og takke Institutt for Spesialpedagogikk, alle kollegaene ved ISP og forskargruppene eg har vore ein del av; CLL og Compros. Det har vore fine år på Blindern. Takk og til Ulrika for samarbeid og faglege samtaler, du har lært meg mykje.

Eg vil også takke mine medstipendiatar, gode kollegaer å dele stipendiatkvardagen med har gjort det fint å kome på jobb. Ei særleg takk til Veerle for di omsorg, humor og gode venskap på vårt vesle kontor- og til Anita, Gøril og Anette, for støtte, gode samtaler og fine stunder. Takk til mine gode vener, som gjer kvardagen så mykje kjekkare.

Kjæraste familien min; mamma og pappa, Hans Marius, Camilla, Anthony, Ivo, Abel, Sondre og Synnøve. Og Helge. Takk.

Christiane Haukedal, Blindern, 10.12.19. 


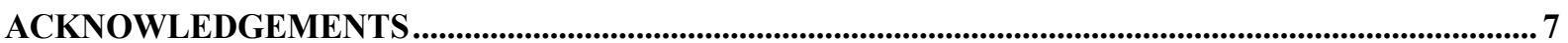

LIST OF PAPERS............................................................................................................................................................. 11

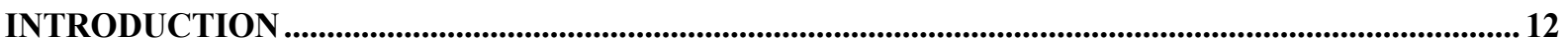

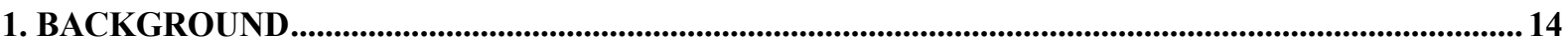

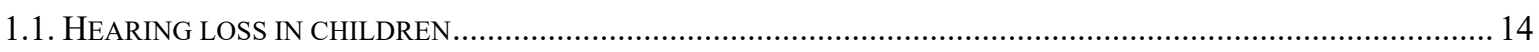

1.1.1. Detection and habilitation of hearing loss in children in Norway .............................................. 15

1.1.2. Brief outline of typical language development …….................................................................. 16

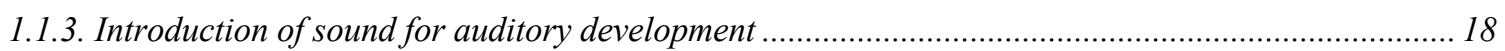

1.1.4. Language outcomes in children with hearing loss .................................................................. 19

1.1.5. Effects of hearing loss and language difficulties on different areas of life ...................................... 22

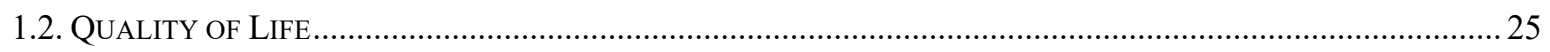

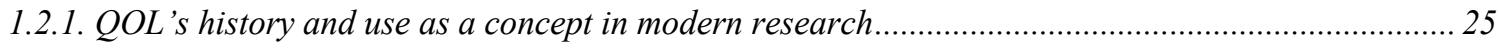

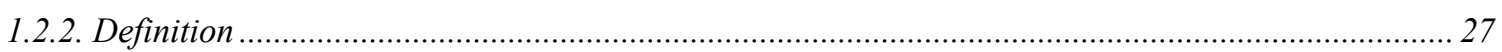

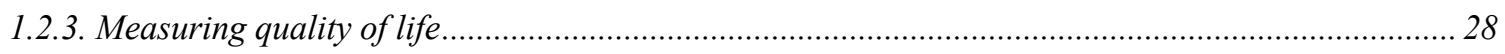

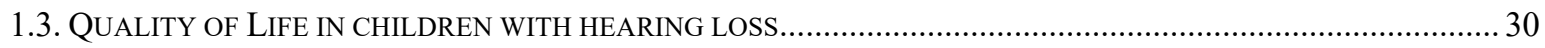

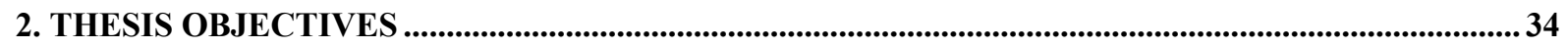

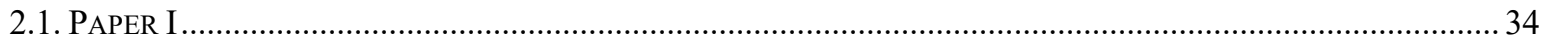

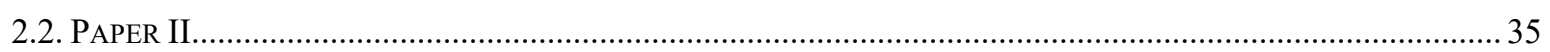

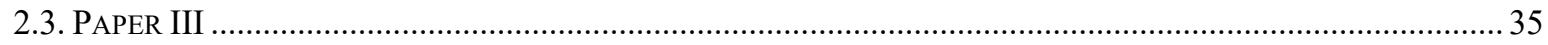

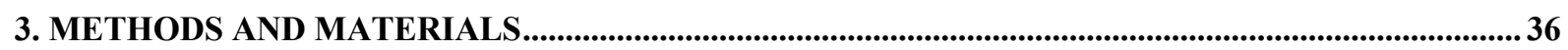

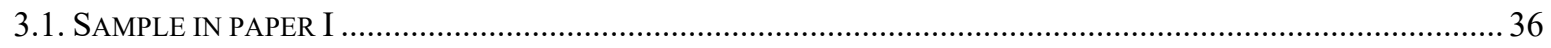

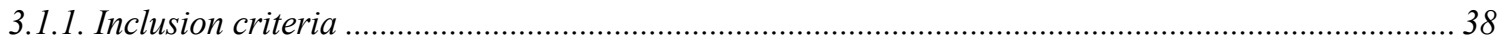

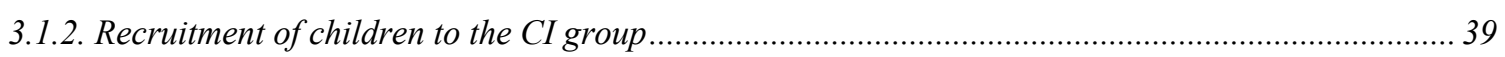

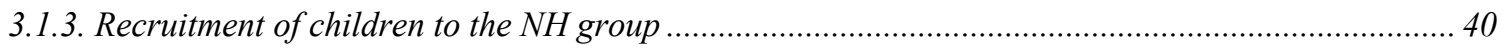

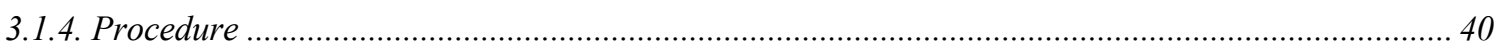

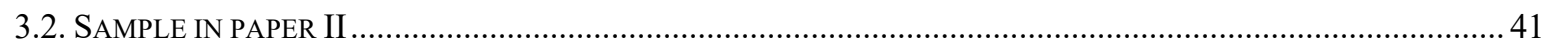

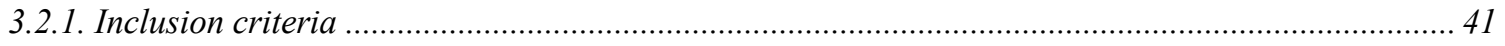

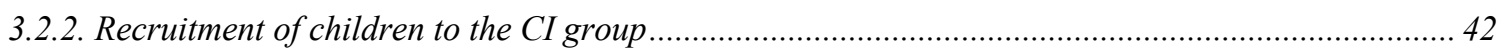

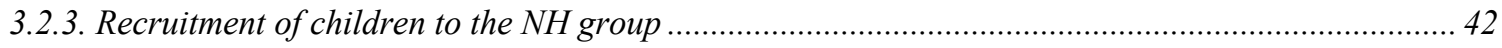

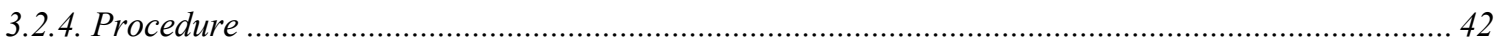

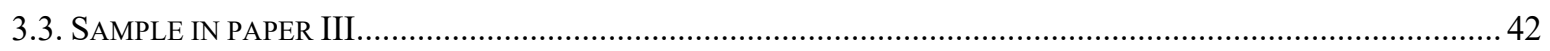

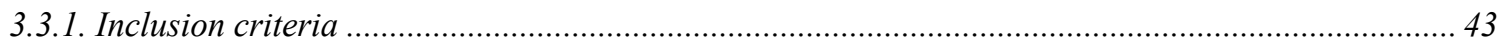

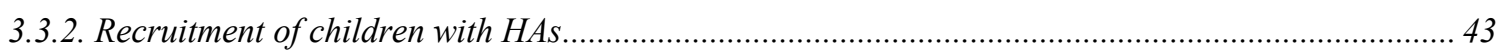

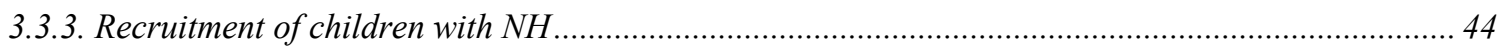

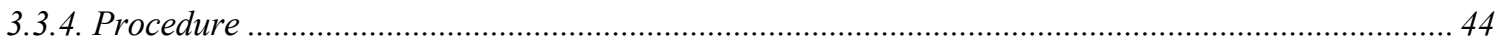

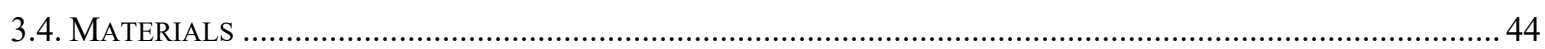




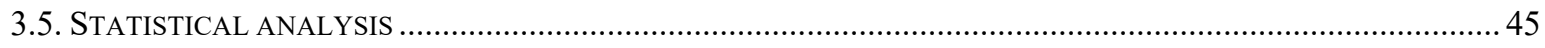

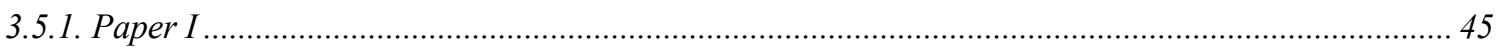

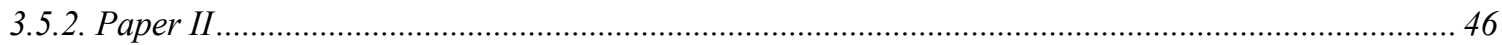

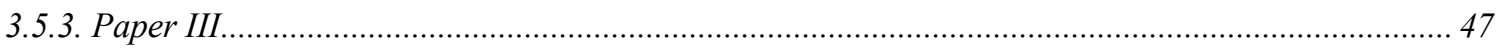

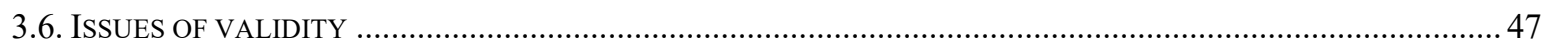

3.6.1. Choice of inclusion criteria and consequences for construct- and external validity ........................ 48

3.6.2. Children with typical development and normal hearing: external validity..................................... 49

3.6.3. Choosing HR-QOL measurement and consequences for construct validity.................................. 50

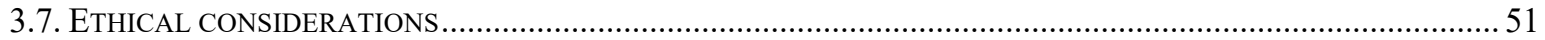

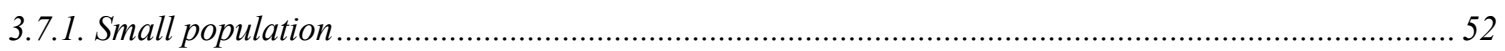

3.7.2. Children in research, weariness of testing and reward for participating ..................................... 52

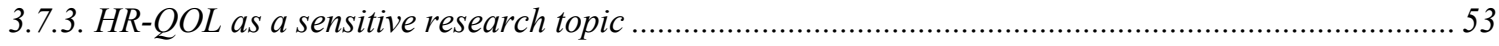

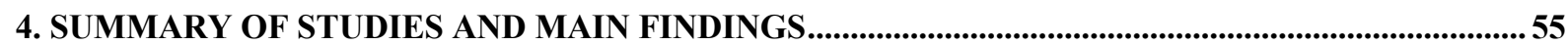

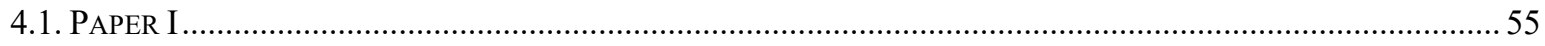

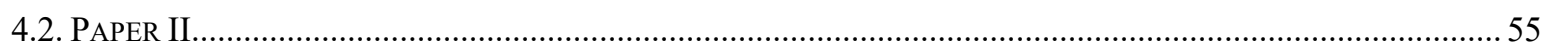

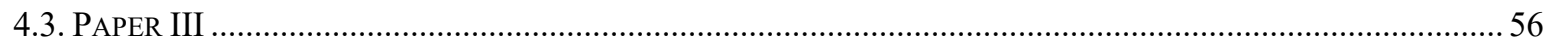

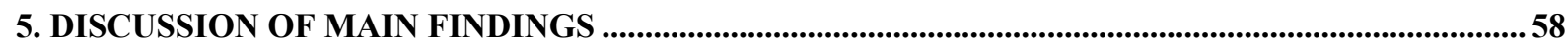

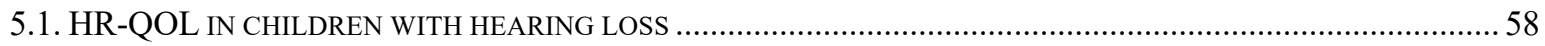

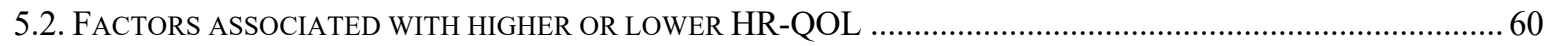

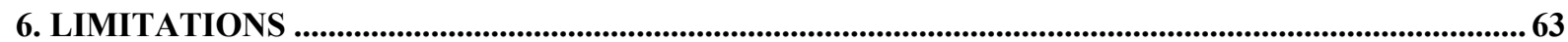

7. CONCLUSION

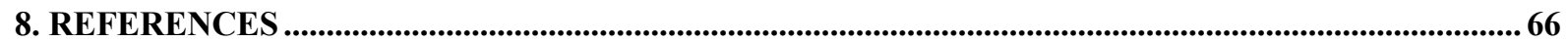




\section{List of papers}

Paper I: Haukedal, C. L., Torkildsen, J. V. K., Lyxell, B. \& Wie, O. B. (2018) Parents' Perception of Health-Related Quality of Life in Children With Cochlear Implants: The Impact of Language Skills and Hearing. Journal of Speech, Language, and Hearing Research, 61(8), 2084-2098.

Paper II: Haukedal, C. L., Lyxell, B. \& Wie, O. B. (2019) Health-Related Quality of Life in Children with Cochlear Implants: The Children's Perspective. Ear \& Hearing. Doi: 10.1097/AUD.0000000000000761

Paper III: Haukedal, C. L., Wie, O. B., Schauber, S. K., Lyxell, B., Fitzpatrick, E. \& Torkildsen, J. V. K. (submitted) Parents' Perception of Communication and Health-Related Quality of Life in Children using Hearing Aids.

The paper is currently under review in Journal of Speech, Language, and Hearing Research.

The papers will be referred to by their Roman numerals. 


\section{Introduction}

Living a good and fulfilling life is a main concern for most of us. We all have dreams of what we wish to accomplish and thoughts about what characterizes the lives we wish to live. "While the quantity of our lives is notoriously limited to one per person" (Michalos, 2015 , p. 1), the quality of our lives is variable and affected by our many and diverse life experiences.

In this thesis you will read more about how children with hearing loss and their parents experience the effects of hearing loss on the children's quality of life (QOL). Living with disabilities, such as childhood hearing loss, can affect life experiences in a variety of ways. It may affect how well children are able to communicate with their surroundings, their academic success, and possibly, later life outcomes such as work satisfaction, employment and health status. QOL in children with hearing loss is a timely topic for research, as today's medical technology can enable children with different degrees of hearing loss to hear and acquire spoken language nearly as or as well as their peers. This was thought to be impossible 30 years ago, when cochlear implants (CIs) were first introduced in children. At first, many voiced strong oppositions to CIs in children with congenital or early acquired hearing loss. They viewed these children as belonging to a cultural minority of Deaf people, as consequence of their hearing status (Lane, 2005). Many deaf people have, throughout history, experienced discrimination because of their deafness and thus viewed the medical advance of cochlear implantation as just another way of attacking their language and culture (Lane, 1993). Proponents argued that children could function perfectly without hearing in a Deaf society, communicating through sign language, and they questioned whether it was ethical to use medical technology to change the hearing status of these children.Concerns were raised about what kind of hearing the CIs would restore, and thus how the implantation might affect the children's psychological health and overall QOL-as they would gain an imperfect hearing in a world of sound (Lane, 1993, 2005).

Much has changed in the years that have passed, especially with regards to identifying hearing loss earlier, making it possible to provide children with proper amplification at younger ages. Today most children with congenital or early acquired hearing loss in Norway receive bilateral CIs or HAs, and the literature on language acquisition among children with hearing loss, given the proper habilitation, is very promising. However, concerns about how children with hearing loss fare mainstream schools persist. 
One challenge when studying the effects of hearing loss on QOL in children, is the high degree of heterogeneity within the population and the wide range of variables that may serve as risk or protective factors in experienced QOL. In addition, children with hearing loss make up a relatively small population in numbers. This may amplify the impact of factors known to affect QOL in children with hearing loss, as well as limit the type of research questions one can answer. Although some factors are thought to affect QOL in children with hearing loss, knowledge within this research area is limited. There is thus a need for studies that can contribute to the knowledge on QOL in children with hearing loss without other complication factors (e.g. additional disabilities). This thesis contributes to the literature on QOL in children with congenital or early acquired hearing loss through examination of a more homogenous group of children and analysis of which variables are associated with a higher or lower reported QOL. The results offer a more nuanced picture of how growing up with hearing loss affects an individual and what services are needed to ensure children with hearing loss have the same potential QOL as children with normal hearing.

In this thesis, I first describe hearing loss in children and the current habilitation situation for children with hearing loss in Norway. In the next chapters, I review the milestones of early language development in both children with typical hearing and children with hearing loss. A review of literature on the relation between language development and different aspects of development follows, followed by a review of the concept of QOL and an overview of the research on QOL in children with hearing loss. Finally, I outline methodologies used, consider methodological issues and ethics and review and discuss the findings of the papers.

The children studied in this thesis communicate primarily through spoken language, and thus, their primary language acquisition occurs through auditory stimuli. I do not, therefore, discuss sign language acquisition or the relation between sign language and QOL. When the terms communication and language skills are used in the following text, they refer to communication based primarily on auditive stimuli and spoken language, if not specified otherwise. 


\section{Background}

\subsection{Hearing loss in children}

Hearing connects individuals to others through speech, emotional sounds and the enjoyment of music. Hearing gives us awareness of what is happening around us and warns of approaching dangers. Inability to hear affects how individuals connect to their surroundings, and untreated hearing loss can greatly affect an individual's life at all ages, and especially when present from birth. Although hearing loss is a condition most people are aware of, many seem to underestimate the number of people affected by this condition.

Permanent hearing loss (greater than $30 \mathrm{~dB}$ ) is estimated to occur in 1-2 children per 1000 newborns in developed countries (Kvaerner \& Arnesen, 1994; Mäki-Torkko, Lindholm, Väryrynen, Leisti, \& Sorri, 1998). According to Statistics Norway (2019), 55120 children were born in Norway in 2018. Based on this statistic, an estimated 55 to 110 children are born with a bilateral hearing loss, exceeding $30 \mathrm{~dB}$ in the better ear, in Norway each year. Further estimates of prevalence of hearing loss largely depends on how hearing loss is defined. A study by Mehra, Eavey \& Keamy (2009) estimated that approximately $3 \%$ of children and adolescents have mild hearing loss or worse, while a study by Feder et al. (2017) found $7.7 \%$ of children or adolescents have some form of hearing loss affecting one or both ears. This indicates that, depending on definition, between $3-7 \%$ of children and adolescents have a hearing loss serious enough to require some school accommodation or that may cause some trouble with hearing in noise. This prevalence is comparable to estimates of the incidence of learning disorders in other specific populations, such as specific language impairment (now developmental language disorder) which is estimated to affect $7 \%$ of children (Leonard, 2014 , p. 3), or dyscalculia which also is estimated to affect about $7 \%$ of children and adolescents (Geary, 2011). The number of individuals experiencing hearing loss gradually increases from childhood to adolescence. Withal, the prevalence of hearing loss increases steeply through adulthood, with approximately half of the population experiencing hearing loss of $30 \mathrm{~dB}$ or worse by 80 years of age (Roth, Hanebuth, \& Probst, 2011).

Although the prevalence of hearing loss depends on the definition used, and moderate to severe losses are less frequent, studies indicate that even a mild or minimal hearing loss may have adverse effects on the individual in a number of areas of life, and this applies to 
both children (Wake \& Poulakis, 2004; Winiger, Alexander, \& Diefendorf, 2016; YoshinagaItano, Johnson, Carpenter, \& Brown, 2008) and adults (Monzani, Galeazzi, Genovese, Marrara, \& Martini, 2008). Hearing loss is thus a major health concern, and measures need to be taken in order to prevent disabling effects at all ages (Wilson, Tucci, Merson, \& O’Donoghue, 2017).

\subsubsection{Detection and habilitation of hearing loss in children in Norway}

Norway implemented national hearing screening for newborns in 2008. National guidelines state that all newborn babies should be offered hearing screening with otoacoustic emissions (OAE) during the first 24 to 72 hours after birth. If a baby does not pass the screening, he or she should be referred to an ear-nose-and-throat department (ENTdepartment) for additional tests within four weeks (Helsedirektoratet, 2017).

Children who are identified with mild to severe hearing loss are usually referred for follow up at their local ear nose and throat (ENT) department, which provides them with proper HAs. HAs comprise three components; microphone, amplifier, and loudspeaker. The microphone picks up acoustical information and converts it to electrical information; the amplifier amplifies the electrical signal at specific frequencies as necessary for the individual's hearing loss; and the loudspeaker converts the signal back to acoustic information (Stach, 2010). How well the hearing aid is able to amplify the required frequencies is dependent upon the severity of loss at the different frequencies, but it cannot provide the individual with normal hearing. If the inner ear hair cells are too damaged, a regular hearing aid will not be sufficient to give the individual adequate access to sound. If the child's hearing loss is not sufficiently mitigated by their HAs, the child is most likely referred for treatment with CI.

While a HA is dependent on the remaining hair cells in the cochlea, a CI bypasses the damaged hair cells stimulating the acoustic nerve directly by use of electrodes implanted in the cochlea. A cochlear implant thus consists of an external and an internal component. The external part is a microphone that picks up acoustic signals and sends them to the processor. The processor sends the signals to a receiver or stimulator that is implanted under the skin, and the signal is transmitted further to the electrode array implanted in the inner ear (Stach, 2010). A HA is dependent upon the residual hearing and may not always be able to reinforce the different frequencies sufficiently. In contrast, are the signals sent by CIs electric, and the implant reinforces all frequencies equally well. 
Oslo University Hospital (OUS), Rikshospitalet, is the national treatment service provider for pediatric cochlear implantation. Thus, all children who receive CIs in Norway have their operation at Rikshospitalet and are followed annually at this CI unit until they are 18 years old. Adults in South-Eastern Norway continue their treatment at Rikshospitalet even after they turn 18, while residents of Western, Mid- and Northern Norway are transferred to their regional hospitals. The costs of all medical care in Norway is covered by the Norwegian state, including costs of surgeries, amplification devices and life-long follow up.

While standards for medical and technical follow up have been formalized in national guidelines, the pedagogical follow up concerning language interventions is less standardized and is subject to more variation depending on where the family lives and the resources available. For the immediate post-diagnosis follow up for children 0-3 years old, the ENT departments that diagnose the hearing loss, or the parents themselves, can contact Statlig spesialpedagogisk tjeneste/ Governmental special educational service (Statped). Statped offers one or two appointments to parents, as part of their Strakstilbudet, during which the parents have the opportunity to talk to professionals about topic such as language development, which courses and guidance exist, and how to contact the local municipality's pedagogisk psykologik tjeneste/ educational psychological service (PPT) (Statlig spesialpedagogisk tjeneste, 2018). However, whether parents receive these benefits depends upon whether the hospital or PPT informs them of this service.

Further follow up for children and their families, regardless of the degree of hearing loss, is the responsibility of local municipalities, all of which have PPTs. PPT will, in their expert assessment, determine which types of help and the amount of help the families will receive, both before the children start kindergarten and during kindergarten and throughout their school experiences. If PPT does not have sufficient competence regarding hearing loss, Statped will support and advise them. In addition, Statped also offer individual guidance to parents and PPT/kindergarten/school, as well as several courses for parents and professionals that are based on seminars (Statlig spesialpedagogisk tjeneste).

\subsubsection{Brief outline of typical language development}

When reviewing early spoken language development in typically developing children, it is clear that access to sound is a prerequisite for this development to occur naturally. The ability to perceive sound develops at approximately 28 weeks gestation, so newborn babies have already been following and processing sounds and voices for several weeks, from inside 
the womb (Graven \& Browne, 2008; Hepper \& Shahidullah, 1994). For example, one study found that two-day-old infants prefer their native language over a foreign language, indicating prenatal exposure to their native language (Moon, Cooper, \& Fifer, 1993). However, the auditory system is continuously developing throughout childhood, undergoing anatomical, functional and perceptual maturation, approaching adult-like hearing in adolescence (Abdala \& Keefe, 2012; Eggermont \& Moore, 2012). Babies younger than six months of age are able to distinguish between sounds, even if those sounds bear no meaning in their ambient/native language. From around six months of age, this ability declines, and the baby gradually starts to prefer and recognize language patterns in the ambient/native language(s) (Jusczyk, 1999; Werker \& Tees, 1984). Studies suggest that better discrimination of native phonemes at seven months of age is predictive of better language skills at 30 months. In contrast, better discrimination of nonnative phonemes at seven months predict poorer language skills later on. This gradual preference for the ambient language may reflect neural changes, through which the perception of native sounds is enhanced, making the perception of these sounds more efficient (Kuhl, Conboy, Padden, Nelson, \& Pruitt, 2005).

Babies, however, do not only perceive sounds and language; they also produce sounds and language to communicate with their surroundings in the form of cry and noncry vocalizations. Five-months-old babies use noncry vocalization to try to re-engage unresponsive adults, indicating some level of understanding of the social impact of vocalization (Goldstein, Schwade, \& Bornstein, 2009). At approximately 6-8 months of age, babies demonstrate expressive language development in the form of canonical babbling, which consists of consonant-vowel combinations that mimic adult speech patterns and words (Oller, 2000; Oller, Eilers, Neal, \& Cobo-Lewis, 1998; Vihman, 2019). Delay in canonical babble has been identified as a risk factor for later difficulties with language or learning and was considered a possible indication of hearing loss, before universal hearing screening had been widely implemented (Oller et al., 1998). As babies grow older, they engage with more with objects in their surroundings. Babies who are 9-12 months old may direct adults' attention towards objects, behaviors or situations of interest, or follow adults' direction, to form joint attention. One mechanism thought to enable children to acquire language and understand cultural cues is their ability to hold joint attention and thus, through shared attention, understand that other people have intentions that drive their behavior (Tomasello, 1999). At closer to one year of age, children utter their first words and gradually expand their 
receptive and expressive language. By the time children are four to five years old, they know most of the basic grammar in their ambient languages (Tetzchner, 2001).

Although language development is most essential and rapid during the first years of childhood, language skills, such as vocabulary, continue to grow throughout life (Tetzchner, 2001). Individual variation in language acquisition during the first few years of life is large and often found to be only moderately associated with later language skills (Bornstein, Hahn, \& Putnick, 2016; Norbury, 2019). Individual language skills seem to become more stable when the child is closer to school age (Bornstein et al., 2016; Norbury, 2019).

\subsubsection{Introduction of sound for auditory development}

As so much of typical spoken language development is dependent on access to auditory stimulation, auditive development in children with hearing loss, depending on degree and onset, may be delayed, possibly due to a period of either partial or complete auditory deprivation. Auditory development depends on individuals being exposed to a variety of auditory stimuli from their surroundings (Graven \& Browne, 2008). If not provided with proper amplification, cross-modal reorganization occurs within the brain due to plasticity; the visual cortex, which receives rich stimuli regardless of hearing status, begins to take over areas of the auditory cortex (Bavelier \& Neville, 2002). For a child who is growing up deaf in a sign language community, this is a positive process, as the brain ensures that much-used skills related to visual language are enhanced. However, for a child to learn to hear and communicate through auditory stimulation, there seems to be an optimal period during which hearing needs to be introduced in order for sound to be meaningful to the individual (Kral \& Sharma, 2012; Peterson, Pisoni, \& Miyamoto, 2010; Sharma, Campbell, \& Cardon, 2015; Sharma, Dorman, \& Spahr, 2002). The duration of this optimal period is highly individual, but studies of electrophysiological data suggest three and a half years as a limit for a more normal auditory development and seven years as the approximate end of the sensitive period (Kral \& Sharma, 2012; Sharma \& Campbell, 2011; Sharma et al., 2002).

Evidence of a sensitive period for implantation can also be seen in behavioral data. Several studies found earlier cochlear implantation resulted in better language outcomes and there is generally a wide consensus for this view. However, what exactly is meant by "earlier" varies. Some find better outcomes if children are implanted before three years old (Manrique, Cervera-Paz, Huarte, \& Molina, 2004; Miyamoto, Svirsky, Kirk, \& Sehgal, 1999) before two years old (Svirsky, Teoh, \& Neuburger, 2004), before 12 months (Ching et al., 2013; Dettman 
et al., 2016; Forli et al., 2011; Leigh, Dettman, Dowell, \& Briggs, 2013; Wie, 2010), and yet others recommend implantation before 9 months (Karltorp et al., 2019). The lack of correlation between age at implantation and later language skills in some studies may be due to low degrees of variability in age at implantation among those studied. Studies that look into group effect of age at implantation typically find an association. Similarly, studies evaluating age at diagnosis or amplification in children using HAs also find that earlier amplification or diagnosis is associated with better language outcomes (Carew et al., 2018; Ching, 2015; Cupples et al., 2018; Sininger, Grimes, \& Christensen, 2010). Earlier amplification and access to sound appears to be important for children with hearing loss regardless of the degree of hearing loss or type of amplification device.

The emphasis on early detection and amplification was also acknowledged in recommendations from the Joint Committee on Infant Hearing (JCIH) in their 1-3-6 approach. Within the first month of life, all children should be screened for hearing loss. Children who do not pass this screening should have a full audiological evaluation within 3 months. If hearing loss is detected, the child should be fitted with amplification within a month of diagnosis, and intervention should be initiated by 6 months of age (Joint Committee on Infant Hearing, 1994, 2007). These guidelines were recently updated to include a recommendation for a 1-2-3 timeline of diagnosis and intervention (Joint Committe on Infant Hearing, 2019).

These recommendations are in line with current research, and suggest utilizing the most optimal period for auditory stimulation in order to prevent cascading effects of hearing loss (Joint Committe on Infant Hearing, 2019). When a child is diagnosed with hearing loss at birth, the child is also at risk for developing communication problems, so the ability to provide early intervention within the first months of life, reducing the risk of future difficulties, is highly beneficial.

\subsubsection{Language outcomes in children with hearing loss}

When providing children with amplification devices such as HAs or CIs, the goal is to allow the development of spoken language skills that are close to, or equivalent to, their peers who do not have hearing loss. Even though numerous studies suggest earlier diagnosis and access to amplification is associated with better outcomes (Carew et al., 2018; Ching, 2015; Ching et al., 2013; Cupples et al., 2018; Dettman et al., 2016; Forli et al., 2011; Geers, Moog, Biedenstein, Brenner, \& Hayes, 2009; Karltorp et al., 2019; Leigh et al., 2013; Manrique et 
al., 2004; Miyamoto et al., 1999; Sininger et al., 2010; Svirsky et al., 2004; Wie, 2010), many studies still indicate that children with hearing loss do not have language outcomes that are as good as their peers. The estimated delays vary, but several studies report group-average language levels of approximately 1-2 standard deviations below the normative mean, based on one or more measures (see e.g.: (Ching, Cupples, \& Marnane, 2019; Ching et al., 2013; Cupples et al., 2018; Lund, 2015; Wake, Hughes, Poulakis, Collins, \& Rickards, 2004; Yoshinaga-Itano, Sedey, Wiggin, \& Chung, 2017)). Furthermore, delays in language development are found across many language domains, including vocabulary (Lund, 2015; Yoshinaga-Itano et al., 2017), grammar (Boons et al., 2013; Halliday, Tuomainen, \& Rosen, 2016; Hammer, Coene, Rooryck, \& Govaerts, 2014; Koehlinger, Van Horne, \& Moeller, 2013), pragmatic language skills (Most, Shina-August, \& Meilijson, 2010), aspects of auditory working memory (Geers, Pisoni, \& Brenner, 2013; Lyxell et al., 2011; Nittrouer, Caldwell-Tarr, \& Lowenstein, 2013; Wass, 2009) and phonological skills (Halliday et al., 2016; Nittrouer, Muir, Teietgens, Moberly, \& Lowenstein, 2018; Wass, 2009). While many studies suggest that some language delay may be present in children with hearing loss, others find that children with different degrees of hearing loss have language scores similar to their peers or within the typical range (Fulcher, Purcell, Baker, \& Munro, 2012), at least in some domains (Fitzpatrick et al., 2012; Halliday et al., 2016). In a study by Fulcher et al. authors showed that if children were identified early, were enrolled in auditory-verbal intervention (AV), and were provided with proper amplification with either HAs or CIs by 18 months, their overall language scores were within normal limits by 5 years old. No difference was found with regards to severity of hearing loss (Fulcher et al., 2012). This study included children who had no additional diagnoses, who used their amplification devices and whose parents attended a minimum number of AV sessions. This result is promising, as it suggests that age-appropriate language development may be within reach for many children, provided they receive appropriate follow-up services.

Although group-wise comparison to peers without hearing loss on average suggest lower language skills, both researchers and clinicians frequently highlight the large variation in individual outcomes among children with hearing loss. Some children develop ageappropriate language skills with CIs or HAs, while others, especially CI users, do not develop useful speech perception or production (Peterson et al., 2010; Pisoni, Kronenberger, Harris, \& Moberly, 2017). Regardless of the type of amplification device used, age at implantation or amplification has been shown to be the most important factor for later language outcomes, but 
a number of additional factors have also been identified, including higher nonverbal IQ (Ching et al., 2019; Cupples et al., 2018; Wie, Falkenberg, Tvete, \& Tomblin, 2007), consistent or sufficient use of amplification (Tomblin et al., 2015; Walker et al., 2015; Wie et al., 2007), absence of additional conditions or disabilities (Ching et al., 2013; Cupples et al., 2018; Yoshinaga-Itano et al., 2017), use of spoken language only rather than sign language in habilitation (Geers et al., 2017; Percy-Smith, Caye-Thomasen, Breinegaard, \& Jensen, 2010) and higher education among mothers (Cupples et al., 2018; Yoshinaga-Itano et al., 2017).

Wie et al. (2007) examined which variables might influence speech perception scores in the first 100 individuals who received CIs as children in Norway. Results showed that, together, daily CI use, nonverbal intelligence, mode of communication, length of CI experience and educational placement accounted for $50 \%$ of observed variation in speech perception. Similarly, in a recent study, Yoshinaga-Itano et al. (2017) examined factors associated with better expressive vocabulary in children 8-39 months of age, with hearing loss of different magnitude and using different amplification devices. Younger age at time of testing, absence of additional disabilities, younger age at detection and intervention (1-3-6), higher maternal educational level, lower severity of hearing loss, and presence of an adult in the family who was deaf or hard of hearing were all factors associated with better vocabulary and together accounted for $41 \%$ of variation in outcomes. Thus, although several factors affecting language outcomes have been identified, much of the variation in outcomes is still unexplained, which makes predictions about the development of individual children difficult.

In addition to the general findings on language outcomes in children with hearing loss, studies have also examined the impact of degree of hearing loss and type of amplification device on language outcomes. HAs and CIs amplify sound in different ways, which may result in differences in what they hear. In addition, as children with less severe losses have better unaided hearing and potentially a less complete period of auditory deprivation, it seems likely they would outperform children with more severe losses. However, the overall picture is far from clear. Some studies indicate no difference in language outcomes in children with HAs compared to children with CIs (Fitzpatrick, Crawford, Ni, \& Durieux-Smith, 2011; Hammer \& Coene, 2016). Others studies find similar or better language outcomes in children with HAs compared to children with CIs (Fitzpatrick et al., 2012), while still others find CI use to be predictive of better language outcomes in children with hearing loss compared HA use (Sininger et al., 2010). In addition, several studies find better language outcomes in children with milder hearing loss (Ching et al., 2013; Cupples et al., 2018; Fitzpatrick et al., 
2011; Sininger et al., 2010; Wake, Hughes, Poulakis, Collins, et al., 2004; Yoshinaga-Itano et al., 2017), while others find no effect from the degree of hearing loss (Carew et al., 2018; Halliday et al., 2016). Some of the observed variation may be related to the tendency for children with milder hearing losses to receive less follow up or wear their amplification devices less frequently than peers with more severe hearing loss (Gustafson, Davis, Hornsby, \& Bess, 2015; Walker et al., 2013; Winiger et al., 2016). Therefore, it is difficult to draw firm conclusions as to whether, or how, the degree hearing loss or type of amplification device used affect language outcomes. Nevertheless, experiencing hearing loss in childhood puts children at risk for delayed language development regardless of degree of loss or type of amplification device used.

\subsubsection{Effects of hearing loss and language difficulties on different areas of life}

Hearing loss and consecutive language delay may not affect only communication, per se. Hearing and language not only allow children to express themselves, but they form the basis of cognition, emotion- and self-regulation, and children's ability to understand others and learn the codes of the culture around them.

Psychosocial difficulties comprise both psychological and social aspects of life, including mental health issues, behavioral problems, relations to others, and self-regulation, and are also related to health outcomes, well-being and QOL (Martikainen, Bartley, \& Lahelma, 2002). Psychosocial difficulties are associated with language difficulties across groups who struggle with language for different reasons. Among Asian American minorities, limited English proficiency has been found to be related to more psychological distress, even after controlling for socio-economic status (SES), discrimination, immigration and demographic variables (Zhang, Hong, Takeuchi, \& Mossakowski, 2012). Studies of children with DLD indicate increased risk of socioemotional problems compared to their peers with no language delay (Conti-Ramsden, Mok, Pickles, \& Durkin, 2013; Yew \& O’Kearney, 2013). Similarly, several studies shows more emotional and behavioral difficulties in children with hearing loss, compared to children with normal hearing, and this is true for both children using HAs and children using CIs (Fellinger, Holzinger, Sattel, Laucht, \& Goldberg, 2009; Stevenson, Kreppner, Pimperton, Worsfold, \& Colin, 2015; Theunissen et al., 2011; Theunissen et al., 2014; Theunissen et al., 2015). There are several possible links between language skills and emotions, although different explanations may be relevant for different groups. Difficulties with understanding and producing language may affect how well children 
recognize and understand emotions in others and how well they are able to identify and understand emotions in themselves (Cole, Armstrong, \& Pemberton, 2010). Furthermore, language may affect how well the child can regulate emotions, e.g. through inner speech or by sharing and reflecting upon emotions with her parents (Cole et al., 2010). For children with DLD, there is a possibility that the causes of language difficulties and emotional and behavioral difficulties may be part of a common underlying etiology. In contrast, for many children with a hearing loss, the cause of their language difficulties is, to some extent, known. This suggests language difficulties can be identified as an important factor contributing to a higher frequency of socioemotional difficulties, although a certain causal relation has not been established. Still, a number of other factors may also contribute for some children with hearing loss, such as underlying etiologies associated with the hearing loss (e.g. cytomegalovirus), difficulties with early attachment, a feeling of stigma for being different, or bullying.

Problems with social interaction or problems with peer interaction has also been reported to be elevated in children with hearing loss (Fellinger, Holzinger, Beitel, Laucht, \& Goldberg, 2009; Huber, Burger, et al., 2015; Stevenson et al., 2015). This may stem from problems with making oneself understood (Fellinger, Holzinger, Sattel, et al., 2009; Stevenson et al., 2015) or understanding others, as difficulty listening in noise may increase risk of social isolation (Huber, Burger, et al., 2015). Another factor that may affect how well children with hearing loss are able to interact with their environment is their ability to mentalize. Mentalization, or theory of mind (TOM), is the ability to understand, interpret and imagine other people's mental states (Fonagy, Gergely, \& Target, 2007). This ability enables the individual to understand others and predict other people's behaviors and mental states. In addition, to be able reflect upon how others are different, one also has to understand one's own thoughts and feelings (Fonagy et al., 2007). TOM has been shown to be closely linked to language development, with earlier language development predicting better TOM abilities (Astington \& Jenkins, 1999). In accordance with this, TOM has been found to be delayed in children with hearing loss (Ketelaar, Rieffe, Wiefferink, \& Frijns, 2013; Netten et al., 2017; Peterson, 2004). Children who receive CIs earlier have shown to have better TOM, even when their language and nonverbal IQ did not differ from children implanted later, indicating that early communication is important (Netten et al., 2017; Sundqvist, Lyxell, Jonsson, \& Heimann, 2014). 
Academic functioning or employment rate may also be affected by hearing loss, language difficulties or problems with speech perception. Older studies of reading abilities in deaf or hard-of-hearing high school students found that they lagged behind peers with no hearing loss, reading, on average, at the level of a fourth grade pupil (Wolk \& Allen, 1984). In a review of studies published between 1997 and 2016, which included children using CIs, Mayer \& Trezek (2018) suggest that many children now achieve scores within age range on reading tests, although there was a wide range of variability in individual achievement within the different studies. A descriptive survey of learning outcomes for students with hearing loss in Norway by Hendar (2012) concludes that, on average, students who have hearing loss have more difficulties achieving desirable learning outcomes. However, there is much variation within the group, with some struggling much more than others (Hendar, 2012). Students' success in school affects whether they go on to complete higher education and whether they are employed as adults. In a study conducted among US adults, hearing loss was associated lower educational achievement, lower income and higher levels of unemployment (Emmett \& Francis, 2015).

Physical health effects have been examined to a lesser degree, although some physical effects from language difficulties and hearing loss have been suggested. One suggested consequence that affects both physical and mental health is fatigue. Children with hearing loss report experiencing fatigue more frequently that children with normal hearing, perhaps due to the constraints of listening when communicating in adverse listening conditions throughout a day (Hornsby et al., 2017; Hornsby, Werfel, Camarata, \& Bess, 2014). Children with poorer language skills also report more cognitive fatigue (Hornsby et al., 2014), and children wearing HAs report more shoulder and neck pain, compared with children using CIs (Anmyr, Olsson, Larson, \& Freijd, 2011).

In summary, hearing loss in children, and the language and communication difficulties that often follow, seem to be risk factors for problems across many aspects of life. When assessing overall outcomes and consequences of hearing loss in children, it may be advantageous to include measures that asses more than one area of life. One way of doing this is by assessing the children's QOL. 


\subsection{Quality of Life}

One of the strengths of QOL as a research concept is that most people have intuitive understanding of what good or poor QOL entails. QOL has even made its way into everyday language, with people and newspapers emphasizing habits and activities that brings better QOL to daily living. These behaviors stretch from recreational activities that bring the individual happiness, such as knitting or watching football, to health-promoting habits, such as eating breakfast and getting enough sleep. In everyday language, the meaning of QOL seem to coincide with what is considered the good life, happiness, or what makes life worth living. Thus, the concept can, in one way, seem very intuitive and serve as an effective way to communicate research to the public. At the same time, it's worth noting that the research definition of QOL is not necessarily equivalent to the popular media or lay person's understanding of QOL.

\subsubsection{QOL's history and use as a concept in modern research}

Thoughts about what makes a good life can be traced back through the philosophical history to such disparate sources as ancient Greek philosophers such as Aristotle and the utilitarian ideas of the 1700s. These philosophical roots may be seen as a predecessors or basic premises for the use of the term QOL within modern research (Nordenfelt, 1991; Ruta, Camfield, \& Donaldson, 2007). The first accounts of the term used within medical research, stem back to the 1960s (Post, 2014). The rates of mortality was long used as a measure of health status in a population (Moriyama, 1968). However, as antibiotics, vaccines and generally better treatment options cured diseases and prolonged the lives of more and more patients, death rates no longer served as an accurate reflection of population health (André, 2003; Moriyama, 1968). In addition, during the latter part of the 1900s, individuals living with chronic illness or disabilities also had increased life expectancies. For these groups, there was no immediate cure, but a rather a need for improving their lives substantially in a qualitative manner. Measures of QOL also provide patients with the opportunity to express their opinion about treatment (Armstrong \& Caldwell, 2004), and highlight ethical considerations of prolonged or discontinued treatment (Nicholson, 1975). QOL also serve as a valuable addition to the WHO's International Classification of Functioning, Disability and Health, which mainly focus on the objective aspects of health (Reindal, 2009; World Health 
Organization, 2007). In contrast, QOL incorporate both the subjective and objective accounts of health and how they affect the individual.

QOL has been used as a way of assessing both the patient's view and effectiveness of treatment and as an opportunity for gaining knowledge about health issues at a populational level. In this way, the use of QOL as a concept has also made its way into public debate to change politics and to secure better rights or equality for vulnerable groups, such as individuals with disabilities. QOL has also been used as a way of allocating the scarce resources in public health service between equally deserving groups, or implementing new technology that can improve patient outcomes, by providing justification for treatment through cost-benefit analysis. The question raised in these articles is whether an expensive treatment provides a significant enough increase in QOL to be justified (Crownson, Semenov, Tucci, \& Niparko, 2017).

Cochlear implantation is an example of one such treatment. A single implant costs more than $200000 \mathrm{NOK}$, before surgery costs, customization of the apparatus, later upgrades and future lifelong follow up. The standard procedure in Norway is to provide children who are profoundly deaf in both ears with bilateral implantation, resulting in purely material costs of more than $400000 \mathrm{NOK}$, through only the first year. Though several studies indicate improved language skills (Fulcher et al., 2012; Geers, Brenner, \& Davidson, 2003), better educational outcomes and better reading skills than those reported before CIs (Duarte, Santos, Rego, \& Nunes, 2016; Geers, 2002; Lyxell et al., 2008), these outcomes alone may not be a sufficient argument to justify this expensive treatment, given that many children with CIs still do not achieve age adequate language skills. Several studies have therefore also investigated the benefit of treatment by assessing pre- and post-implant QOL and considering possible future savings for the state, such as higher employment rates due to better educational outcomes and overall better health status. Results showed that the increase in QOL is so significant that it justifies the costs associated with implantation (Crownson et al., 2017), and that bilateral implantation may improve QOL even further than unilateral (Summerfield, Lovett, Bellenger, \& Batten, 2010). Cost-benefit analyses are more common in countries that do not have welfare states such as the Nordic countries do. However, the health care systems in Scandinavian countries also depend on research to allocate public money in ways that provide the most benefit to as many as possible, and argument about QOL improvement are important for determining what is most beneficial. 


\subsubsection{Definition}

There are many definitions of QOL. Some definitions are very broad, such as the one proposed by Torrance (1987, p. 593) in which "QOL is defined as a broad concept that incorporates all aspects of an individual's existence". This definition may be challenging to operationalize for health research, and a more commonly used definition is the one formulated by the World Health Organization (WHO). The definition is highly inspired by the WHO's earlier definition of health from 1948, where health is defined as “... a state of complete physical, mental and social well-being and not merely the absence of disease or infirmity" (World Health Organization, 1948). This definition of health has been debated, as some claim it better describes happiness than health (Spitzer, 1987). Nevertheless, the definition of health is referred to as a predecessor of the more comprehensive definition of QOL:

Individuals' perception of their position in life in the context of culture and value systems in which they live and in relation to their goals, expectations, standards and concerns. It is a broad ranging concept affected in a complex way by the persons' physical health, psychological state, level of independence, social relationships and their relationship to salient features of their environment (Saxena \& Orley, 1997, p. 263).

The WHO's definition of QOL highlights the concept as being highly subjective and multidimensional, as well as encompassing several aspects of life (Saxena \& Orley, 1997; The WHOQOL Group, 1995). When taking the WHO's definition of health into account, some of what makes this definition to stand out from others is the inclusion of social functioning and the acknowledgement of health to be more than the absence of disease (Karimi \& Brazier, 2016). The most commonly used definitions of QOL within the social sciences and medical research usually include, at a minimum, some consideration of physical health and psychological and social well-being (Davis et al., 2006; Spitzer, 1987; The WHOQOL Group, 1995). Thus, based on these definitions, poor functioning in either domain included in the concept would equate to decreased QOL.

The concept investigated in the current thesis and papers is Health-related QOL (HRQOL). There are different opinions as to what "health-related" adds to the concept of QOL. Some argue for strict differentiation between QOL and HR-QOL, with the latter being a subconcept only encompassing clear health aspects such as physical and emotional functioning, which both can have associated illnesses or disabilities. Social functioning is, in this 
understanding, regarded as part of overall QOL, but not as part of what can be considered part of health (Torrance, 1987). However, with the knowledge of how important social interaction and connection to others is for our mental and physical health, it is hard to argue that this has no place in a holistic understanding of what health entails. The definition of HR-QOL put forward by Hays \& Reeve (2008) captures a holistic view of health; "how well a person functions in their life and his or her perceived well- being in physical, mental, and social domains of health" (p. 241). This definition highlights both functioning dimensions in everyday activities that are observable behaviors, such as walking and personal hygiene, and subjective well-being, which encompass inner experiences not readily observable to a person's surroundings, such as pain or anxiety (Hays \& Reeve, 2008). This definition incorporates many of the same concepts as the WHO's definition of QOL, but it offers a definition of the concept of HR-QOL more operationalized to behaviors and perceptions related to the domains of physical, mental and social well-being. This definition best captures the aim of the current studies, as so much of what affects QOL in children with hearing loss is related to socioemotional aspects of life. Another range of concepts that may either be confused with, or used interchangeably with, HR-QOL are concepts more related to emotions and sensations, such as happiness or well-being. Well-being may be said to include both sensory perceptions, emotions and moods of positive denomination (Nordenfelt, 1991), while happiness is more related to the presence of positive and absence of negative emotions (Ruta et al., 2007). Happiness, and the related term pleasure, may be seen as more volatile emotional states, while QOL often is considered to be a more long-term state of mind (Ruta et al., 2007).

\subsubsection{Measuring quality of life}

As there is no single theory or definition of QOL that researchers agree upon, there are also several ways of measuring QOL. Still, most approaches use either a type of questionnaire or interviews to assess QOL. There are two main approaches to measuring QOL; a subjective and an objective approach (Cummins, 2000). Approaches that focus on the subjective aspects of QOL focus on how the individual feel as most important. In contrast, the objective approach, in addition to consideration of how the individual feels, also includes a measure of how well the individual functions in different situations. There are several ways to operationalize this. Some focus on health through health-status or health-utility measures. In these types of measures, the individual's health status is rated on a scale of 0.0 to 1.0 , with 1.0 
meaning the individual is healthy and 0.0 meaning the individual is unconscious or dead (Fanshel \& Bush, 1970; Torrance, 1987). Different conditions that affect health, ranging from physical to psychological, can cause a reduction in health, with, for instance, being depressed and lonely resulting in a utility score of 0.45 (Torrance, 1987). In the same tradition, we find questionnaires that focus on daily functioning, often divided into different domains such as physical health, emotional functioning and social functioning. Although the more objective measures also consider how well individuals are functioning in their everyday environments, a common point for both approaches are that they assess the subjective perception of either well-being or function.

In many studies of clinical populations such as children with varying degrees of hearing loss, authors use so-called disease- or condition-specific questionnaires. These HRQOL questionnaires are specifically designed to tap into areas of interest that might be challenging in the particular patient group (Fayers \& Machin, 2007) and more accurately detect how the individual perceives effects of an intervention or effects of a condition such as hearing loss on different areas of everyday functioning (Umansky, Jeffe, \& Lieu, 2011). Some suggest that generic questionnaires may underestimate the difficulties children with hearing loss face by not sufficiently measuring the unique impact of hearing loss on QOL (Roland et al., 2016; Umansky et al., 2011). A problem with condition-specific questionnaire, however, is that they may not always be suitable for assessing QOL in the general population. In contrast, generic questionnaires are applicable to both healthy and clinical study groups, thus enables comparison between the groups (Fayers \& Machin, 2007). For hearing loss specifically, reviews of the literature indicate that the effects of hearing loss are so broad ranging that generic questionnaires do indeed detect differences in HR-QOL between individuals with hearing loss and their normal-hearing peers (Lin \& Niparko, 2006; Roland et al., 2016), and a specific and different QOL related to hearing loss may not be necessary.

In contrast to other many other types of traditional health measures such as blood pressure or fever, QOL is not necessarily accessible for others to observe or measure directly. The collection of self-reports is generally recommended, if possible, because proxies may perceive the impact of factors such as illness differently than do the individuals affected (Fayers \& Machin, 2007). There are, however, exceptions. Very young children are not able to self-report, and in these cases, parents may serve as the only possible sources to assess QOL. Studies indicate that from about four years old, children are able to self-report on questions that evaluate concrete, everyday conditions, and from approximately eight years 
old, they may also report on more abstract aspects of functioning (Matza, Swensen, Flood, Secnik, \& Leidy, 2004).

When both parent-proxy and self-reports are collected, they provide valuable information on how the child is doing. As QOL is a subjective concept and measure, it is natural to assume the children themselves best know how they are doing. However, several studies find poor agreement between parent-proxy and self-report of QOL in children. This has been interpreted by some as indication that parents do not always have accurate insight into their children's QOL. Studies suggest that parents of typically developing children tend to overestimate their children's QOL, while parents of children with chronic health conditions seem to report lower QOL than do the affected children themselves (Eiser \& Jenney, 2007).

However, it may also be that parents and children perceive the same situation differently. While children may be more prone to respond based on their experience of the here and now, parents' perceptions may be influenced by things they see the children miss out on or worry about the children's futures. Parents' perception of their children's QOL may also be important to assess, especially in children who have different health conditions. Parents' perceptions of QOL and health status are usually what determines whether or not parents contact healthcare services on behalf of their children if they have concerns about their children's health or development (Janicke, Finney, \& Riley, 2001).

\subsection{Quality of Life in children with hearing loss}

As we have discussed so far, a multi-dimensional concept such as QOL may be a useful measure of outcomes of how hearing loss and language difficulties affect children. Several studies have been published on QOL in children with hearing loss, including three attempts at systematic reviews of the literature.

The first review was authored by Lin and Niparko (2006) and targeted QOL in children using CIs, specifically. At the time of the review, only 10 articles were identified and considered eligible. The authors described how a wide variety of measures were used and how heterogeneous the groups studied in the different articles were. This prevented a quantitative analysis of the articles, and no overall conclusion was provided. In this early attempt at metanalysis, many of the studies included children who were implanted late with participants implanted prior to two years old in the same groups. The authors recommended 
future studies use more well-defined groups and well-validated, generic QOL questionnaires to promote less biased conclusions (Lin \& Niparko, 2006).

In 2013, another review of QOL in children with CIs was published by Morettin et al. (2013). Papers published between the years 2000 and 2011 were included. Ten studies were identified as fulfilling the inclusion criteria. As in the previous review, Morettin et al. (2013) also noted high degrees of heterogeneity in the study populations, as well significant variations in how QOL was assessed, and no overall conclusion was reached. Authors in this study also recommend future studies apply standardized generic or condition-specific questionnaires.

Finally, Roland et al. (2016) published a systematic review and meta-analysis of QOL in children with hearing loss, not limited to children with CIs. Using the broader inclusion criteria, 40 papers were included in the review. The authors noted variability in the studies' purposes; the majority of studies used QOL as a tool for evaluating intervention outcomes (fitting of amplification device); some compared QOL between children with hearing loss and normal-hearing peers; and yet others focused on different aspects of QOL in children with hearing loss. Only four studies were deemed eligible for inclusion in a meta-analysis. The overall finding from these studies were that, on average, children with hearing loss report lower levels of QOL in social and school performance, domains compared with peers with no hearing loss, and other areas were not significantly different. Furthermore, the review showed that QOL improved with interventions with amplification devices. As in the previous studies, the authors noted the wide variety of measures used (Roland et al., 2016).

These three literature reviews summarize the results from research on QOL in children with hearing loss by illustrating the extensive variation in outcomes. Regardless of the type of amplification device used and degree of hearing loss, several of studies find similar levels of QOL in children with hearing loss compared to children with normal hearing (Domellof, Hedlund, \& Odman, 2014; Duarte, Santos, Rego, \& Nunes, 2014; Hintermair, 2011; Loy, Warner-Czyz, Tong, Tobey, \& Roland, 2010; Meserole et al., 2014; Perez-Mora et al., 2012; Razafimahefa-Raoelina et al., 2016; Warner-Czyz, Loy, Roland, Tong, \& Tobey, 2009). At the same time, a number of studies find that children with hearing loss have lower levels of QOL than their peers with no hearing loss (Fellinger, Holzinger, Sattel, \& Laucht, 2008; Huber, 2005; Keilmann, Limberger, \& Mann, 2007; Nimensivu, Roine, Sintonen, \& Kentala, 2018; Wake, Hughes, Poulakis, \& Collins, 2004), at least on some domains (Haukedal, Lyxell, \& Wie, 2019; Haukedal, Torkildsen, Lyxell, \& Wie, 2018; Roland et al., 2016). 
Thus, published research does not provide a clear picture, but rather points to two main challenges in studying QOL in children with hearing loss: first, there is much heterogeneity in study samples across variables known to affect both utilization of amplification device and language development. The population of children with hearing loss is relatively small; thus, differences known to affect language and hearing may be amplified by the small sample size included in these studies. This prevents previous studies from making overall prediction of QOL in children with hearing loss. Second, there is a vast variability in how QOL has been measured, with some studies assessing health status, some assessing behavioral or emotional aspects, and some assessing happiness or well-being. As QOL is measured by the assessment of several factors, a diminished score on any one of the domains results in depressed QOL. In addition, fewer studies examined QOL specifically, compared to studies on mental health, for example. This adds to the complexity of the overall picture.

When studying QOL in children with hearing loss, it is challenging to treat children with hearing loss as a uniform group, although there are some overall tendencies. As previously reviewed, a number of different variables affect QOL directly or indirectly. One example is age at amplification/implantation or diagnosis, which has been found to be associated with higher QOL (Korver et al., 2010; Loy et al., 2010). Age at diagnosis or amplification directly affects QOL by providing children with better hearing than those who received amplification late, as well as earlier access to communication with parents, which supports attachment and TOM development. Age at amplification has a more indirect effect on QOL as earlier intervention increases the likelihood of developing normal language skills, resulting in better social interaction with peers and better speech-in-noise understanding.

Other factors previously found to be associated to better QOL, or better functioning on closely related areas such as social interaction, mental health, etc., that are part of the QOL concept, are better language or communication skills (Dammeyer, 2009; Haukedal et al., 2019; Haukedal et al., 2018; Theunissen et al., 2014), use of spoken language rather than sign language or total communication (Percy-Smith et al., 2008), absence of additional disabilities or higher nonverbal IQ (Dammeyer, 2009; Sach \& Barton, 2007; Theunissen et al., 2014; Zaidman-Zait, Curle, Jamieson, Chia, \& Kozak, 2017), female gender (Dammeyer, 2009; Laugen, Jacobsen, Rieffe, \& Wichstrøm, 2016; Sach \& Barton, 2007), attendance at mainstream schools (Huber, Pletzer, et al., 2015; Theunissen et al., 2014), and higher SES or higher completed maternal education (Kirman \& Sari, 2013; Sach \& Barton, 2007). Degree of 
hearing loss has not been shown to be consistently associated with higher or lower QOL. Some studies find a tendency for better psychosocial functioning or QOL in children with milder losses (Nimensivu et al., 2018), while others do not (Laugen et al., 2016; Stevenson et al., 2010; Wong et al., 2017). One study found the opposite trend, with poorer QOL in children with milder losses compared to those with more severe losses (Wake, Hughes, Poulakis, \& Collins, 2004).

The factors that affect QOL in children with hearing loss make up a complex picture, in which different risk or protective factors may influence the child's QOL either directly or indirectly. Several factors found to be associated with better QOL were also associated with better outcomes related to hearing and language development. Poor QOL may thus be a problem that is prevalent among specific subgroups of children with hearing loss, rather than something that is common to all children with hearing loss. In addition, as QOL encompasses several subdomains, children with hearing loss may be more prone to have problems related to those subdomains, rather than problems that affect overall QOL. 


\section{Thesis Objectives}

When planning the articles included in this thesis, we took into account that children with hearing loss are at risk for language delays. Communication and language affect a number of different aspects of children's lives in a complex manner, and assessing QOL offers the ability to measure the overall impact of hearing loss on everyday functioning in children. However, QOL is a poorly defined measure, and there is a great deal of heterogeneity among children with hearing loss relative to a number of variables known to directly or indirectly affect QOL. This has led authors of previous reviews of the literature on QOL in children with hearing loss to request large scale studies that use validated generic questionnaires in well-defined populations of children with hearing loss. These recommendations inspired the objectives in the current thesis.

The overall purpose of this thesis is to examine whether hearing loss affects HR-QOL in children with different degrees of hearing loss but otherwise typical development. The second main question addressed was whether better language and communication skills in children with hearing loss were associated with higher or lower HR-QOL. In addition, the papers also examined other factors previously found to be associated with QOL or psychosocial issues, such as age at implantation or diagnosis, chronological age, nonverbal abilities and socioeconomic status. These questions were examined through three different articles assessing HR-QOL in groups of children 5 to 12 years old, who all had bilateral hearing loss that was treated with some form of amplification device.

\subsection{Paper I}

In the first paper, the main objective was to assess how parents of children with CIs rate their children's HR-QOL, compared to parents of children with normal hearing and typical development in the same age range. Different background variables such as language skills, hearing in everyday situations, age at implantation and socioeconomic status, were examined in order to determine which factors were associated with a higher or lower proxyreported HR-QOL. The paper provides additional knowledge about the areas of HR-QOL that parents perceive to be challenging for their children, and identification of factors associated with higher or lower HR-QOL provides valuable insights into how these challenges may be improved. 


\subsection{Paper II}

The main objective in paper II was to further examine HR-QOL in the same children as in paper I, only this time in light of the children's own perception through self-reported HR-QOL. Previous research indicates that children and parents do not always agree on ratings of HR-QOL, so it is important to assess both the children's and parents' views. In paper II, self-reported HR-QOL in children with CIs was compared to that of age and gender-matched controls. In addition, agreement between proxy- and self-reported HR-QOL in the CI group was examined, and individual and environmental variables were assessed to determine if they were associated with higher or lower self-reported HR-QOL. Results from this paper contribute to a more nuanced interpretation of the status of the children's HR-QOL and also highlight possible areas the children themselves find challenging. Combined with results from paper I, paper II provides additional information about areas and factors where further intervention might help children with CIs experience HR-QOL similar to normal-hearing peers.

\subsection{Paper III}

In the third paper, the aim was to broaden the focus of HR-QOL and hearing loss by investigating how parents of children using HAs perceive their children's level of communication skills and HR-QOL, compared to reports from parents of children with normal hearing. The hypothesis underlying the study was that children using HAs, even if they have no additional disabilities, experience the same challenges as do children with CIs, with regards language delays and possible poorer HR-QOL than their normal-hearing peers. This group has received less attention in the research literature, and fewer studies have examined this group in isolation. In addition to comparing communication abilities between groups, the study also aimed quantify the number of children with communication difficulties in each group. The paper further examined which variables were associated with higher or lower scores on proxy-reported communication and HR-QOL respectively.

Areas of challenge identified in this paper represent potential areas for improved follow-up care and possible areas of interest for future research involving children using HAs. 


\section{Methods and Materials}

The data that underlies the research in the three articles in this thesis all stem from the same larger research project: Speech perception, language and quality of life in people who received CIs as children in Norway between 1988 and 2015. This was a national project that was initiated to evaluate the results of pediatric cochlear implantation in Norway. The project was funded by the Norwegian Directory of Health and was executed in a collaboration between Oslo University Hospital and the University of Oslo (UIO).

As Oslo University Hospital, Rikshospitalet is the national treatment service for cochlear implantation for children, all children who received CIs in Norway underwent surgery at this hospital. This centralization made it possible to extend invitations to all individuals who had received CIs as children (before the age of 18) between 1988 and 2015. comprising a total of 606 children and adults (see box 1, figure 1) whose ages ranged from 1 year to 41 years. The goal of the national project was to increase knowledge about CI recipients, regardless of current status of CI use, additional disabilities, communication mode or native language, and thus the only inclusion criteria was that they had received CIs as children during the given time frame. Project planning began in the fall of 2012. Testing was conducted from the fall of 2013 until the fall of 2016, by which time, $80 \%$ of the target population had agreed to participate in the project (see box 2, figure 1).

In the fall of 2014, the decision was made to include additional populations of children to the main project, including children with normal hearing and typical development, children with DLD, and children with hearing loss in the moderate to severe range using HAs. The children with normal hearing and typical development form the control group used in papers I and III (see box 6, figure 1). The children with HAs are the subject of paper III (see box 9, figure 1). These participants were tested during 2015.

In the fall of 2017, an additional subgroup of children with normal hearing was recruited for the study, as a comparison group in paper II (see box 8 , figure 1).

\subsection{Sample in paper I}

The final sample that was analyzed in paper I included a total of 186 children: 106 children with CIs (53\% boys, $47 \%$ girls), and 80 children with normal hearing (44\% boys, $56 \%$ girls). The children had a mean age of 110 months (range $60.58-155.73$ ) in the CI 


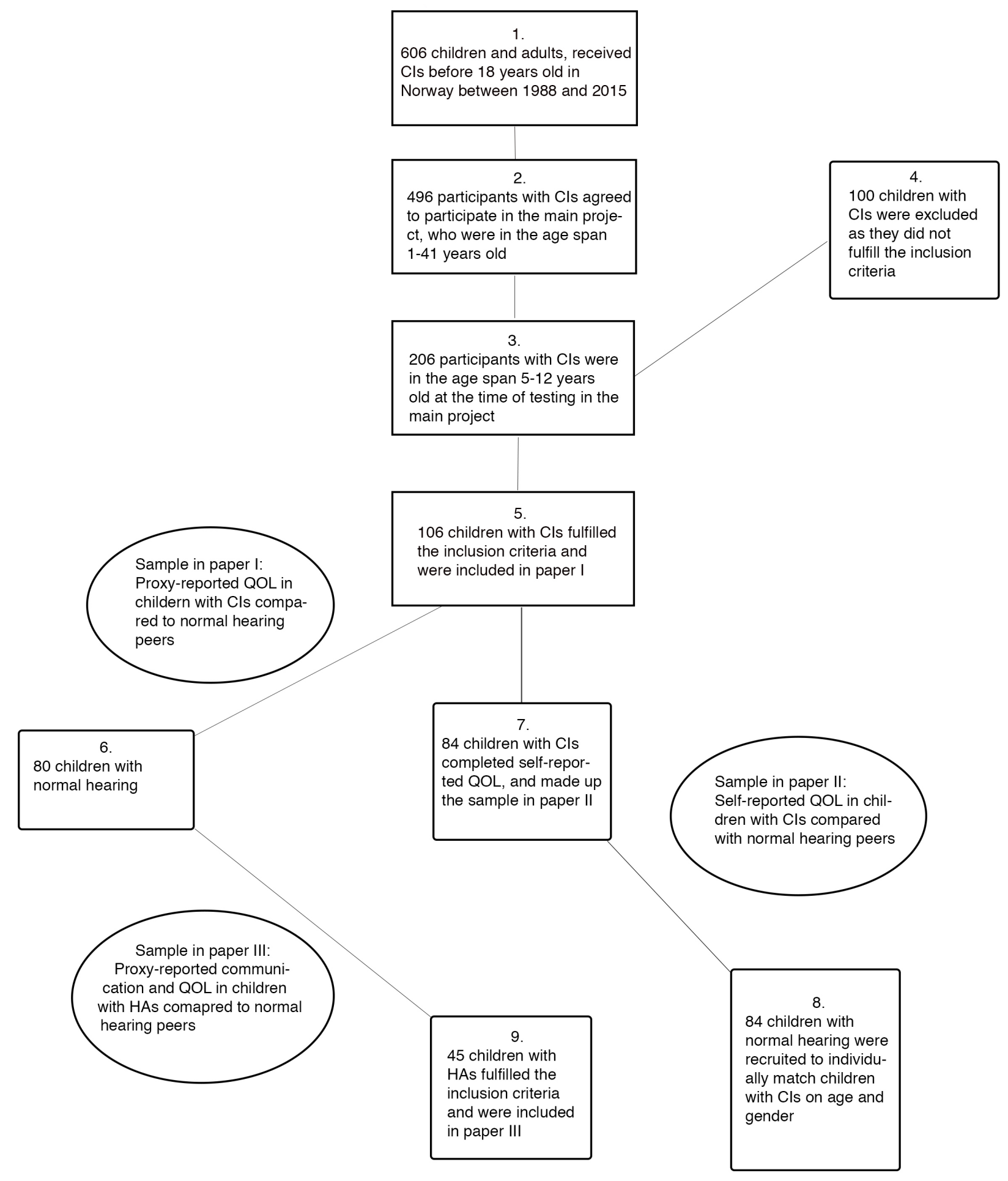

Figure 1. Flowchart showing the number of participants excluded, recruitment of control groups and the sample groups in each paper. The flowchart shows the population of individuals who received CIs as children (1) and how many of them agreed to participate in the national project (2). After completing data collection, the number of children tested in the right age span (3) were identified, some were excluded (4), and a final sample of children with CIs who met the inclusion criteria was selected (5). A comparison group of children with normal hearing was recruited (6), and together with children with CIs (5), they made up the sample in paper I. In paper II, only the children in the CI group who had completed self- reported HR-QOL were included (7), and a comparison group that was individually matched to the CI group was recruited (8). In addition, children using HAs were recruited (9), and their results were compared to the initial group of children with normal hearing (6) and made up the sample in paper III. 
group and 114 months (range $68.11-158.82$ ) in the NH group. Children in both groups had nonverbal IQs in the normal range.

The CI group had an average age at implantation of 34.13 months. However, this included both children with progressive hearing loss and children who became deaf before 35 months. For the subsample of children who were born deaf or became deaf within the first year, $\mathrm{n}=58$, the mean age at implantation was 20.78 months.

Children in the CI group predominantly used spoken language for communication, $68 \%$, while an additional $17 \%$ reported the use spoken language with occasional use of total communication. The remaining children, $15 \%$, used a mix of spoken language and total communication or switched between spoken language and sign language.

Children in the normal hearing group were tested to confirm they had normal hearing and typical development. The groups did not differ significantly on age at testing, gender or nonverbal IQ. However, more children in the NH group than in the CI group had mothers with higher education. In the NH group, $84 \%$ of mothers had completed at least one year of university or college, in contrast to $63 \%$ in the CI group.

\subsubsection{Inclusion criteria}

The goal of paper I was to compare parent-reported HR-QOL in school-aged children with different degrees of hearing loss but otherwise typical development to that of children with normal hearing and typical development. Furthermore, paper I aimed to identify factors associated with higher or lower parent-reported HR-QOL in the CI group. A set of inclusion criteria were formulated in order to encompass this:

1. Age at time of testing between five and 12 years old.

2. Standard score above 74 on a test of nonverbal IQ.

3. No additional disabilities known to affect language development or HR-QOL.

4. Norwegian as their first language for the child, and at least one parent who had either Norwegian or another Scandinavian language as their first language.

The rationale for inclusion criterion one was to limit the selection to children who were in elementary school. This is a period before the children reach adolescence, but where they have started formal schooling. The purpose of inclusion criteria two and three was to 
avoid inclusion of children with intellectual or additional physical disabilities. The absence of other disabilities is associated with better QOL. If not excluded from the current studies, additional disability, such as blindness, cerebral palsy or diabetes, could serve as confounding factors for eventual poor QOL scores in the groups of children with hearing loss. Finally, criterion four was included because our initial hypothesis was that better language skills are associated with better QOL. As children who are sequential bilinguals may be more at risk of language difficulties in their second language, we choose to exclude children whose first language was not Norwegian. This reduced the potential for the presence of other causes of language delay, outside of hearing loss.

For children with normal hearing, the inclusion criteria were the same as for children with CIs. In addition, prior to their participation, the children in the NH group were tested with OAE to ensure hearing thresholds better than $30 \mathrm{~dB}$ HL.

\subsubsection{Recruitment of children to the CI group}

After data collection was completed in the main project, the sample of children with CIs were selected from the main project according to the described inclusion criteria. Of the 206 children tested in the main project who were in the right age range at time of testing (see box 3, figure 1), 106 children fulfilled the inclusion criteria (see box 5, figure 1), and 100 children were excluded for various reasons (see box 4, figure 1). The most common causes for exclusion were nonverbal IQs below $75(n=44)$, the presence of additional disabilities that could affect cognition or language $(n=32)$, and first languages other than Norwegian ( $n$ $=24$ ). As the project was conducted at the CI unit, all participating children with CIs were recruited and tested in conjunction with their yearly follow up at the CI unit. In collaboration with the patient coordinator, an information sheet about the project (see appendix I for an example of the information letter in Norwegian to the participants in the CI group, and appendix II for an English version) was sent to families with the letter announcing the date and time for their scheduled follow-up appointment. Prior to the appointment, research assistants employed in the project contacted the children's parents by phone to ask whether they would like to participate. If they agreed, the research assistants met the family at the hospital when they arrived for their annual checkup. 


\subsubsection{Recruitment of children to the NH group}

A total of 80 children with normal hearing were recruited partly from the networks of research assistants and partly through random selection from urban and rural schools in eastern parts of Norway (see box 6, figure 1). For the recruitment of children through schools, teachers were instructed to distribute information sheet to children who did not receive special needs education to reduce the chance of recruiting children with learning disorders. Parents who agreed to participate returned signed consent form to the school, which were then collected and passed on to research assistants employed in the project. Most children were tested at school, though some were tested at home or at the hospital.

\subsubsection{Procedure}

Before testing, parents were informed that the testing for children aged five to eight years, the full battery of test, without breaks, would take approximately two and a half hours to administrate, while for children aged nine to twelve, it would take approximately three and a half hours. These estimates were generous in order to ensure an adequate time frame was presented to parents when recruiting them, and children did not usually need the full time to complete all tasks. Children were provided with many breaks during testing, including lunch breaks. Depending on the number of breaks and the child's motivation and endurance, the testing process usually lasted about four hours. For some, the duration of testing was too long to complete in a single session, and those children completed the tests over two sessions, on separate days. As children in the CI group lived in all parts of Norway, test sessions sometimes took place several months apart. In contrast, most children in the NH group completed the test sessions within a couple of weeks, as they lived in closer proximity to Oslo.

During the test sessions, children received small toys, such as balloons, erasers, stickers, small cars, Lego figures or bouncy balls, etc. to boost their motivation and endurance. After completing the testing, all children received two gift cards for movie tickets as a thank you for taking the time to participate. All children were also informed that they had been entered into a drawing for an iPad during the semester in which they participated. 


\subsection{Sample in paper II}

The final sample that was analyzed in paper II included a total of 168 children: 84 children with CIs (54\% boys, $46 \%$ girls), and 84 children with normal hearing (54\% boys, $46 \%$ girls). The children in the CI group had a mean age of 120 months (range 67.2 156.0), and in the NH group, the mean age was 119 months (range $73.2-158.3$ ). The groups were individually matched on gender and age at testing $(+/-6$ months of the child with CIs age). The groups were not matched on mothers' educational levels, but they were similar in this aspect: $65 \%$ of the children in the CI group had a mother with some completed higher education, compared to $72 \%$ in the NH group.

The children in the CI group were the same as previously described in paper I, with the exception that not all children in the former study were able to self-report on the HR-QOL questionnaire, resulting in 22 fewer children with CIs in paper II (see box 7, figure 1). The children who did not complete the self-report failed to do so predominantly because they were too young to understand the questions. The mean age in paper II was thus almost one year older than in paper I. Although age at testing was different, other characteristics in the CI group were similar as described on page 38 in paper I.

\subsubsection{Inclusion criteria}

For the children in the CI group, the inclusion criteria in paper II were the same as described in paper I (see page 38).

The children in the NH group did not complete the whole battery of test and were tested on neither hearing nor nonverbal. Rather, the schools at which the children were recruited were instructed to distribute the questionnaires only to children who matched children in the CI group individually on age at testing and gender, and who: (1) had Norwegian as their first language, (2) did not have any additional disabilities known to the schools, and (3) did not receive special needs education. In questionnaires the parents completed together with the consent forms, they were also asked about the children's hearing status and whether they had any concerns for their children's development. If the parents indicated concerns on any of these questions, the child was not included in the final sample. 


\subsubsection{Recruitment of children to the CI group}

Recruitment of children to the CI group was the same as described on page 39 in the presentation of paper I.

\subsubsection{Recruitment of children to the NH group}

The NH group was recruited after the CI group, and participants were selected to be matched individually on age (+/- 6 months of the child with CIs age) and gender to the children in the CI group (see box 8, figure 1). The schools collected signed information forms from parents who agreed to participate, and the schools passed the collected consent forms on to the research assistants employed in the project.

The children were recruited from one school in southeastern part of Norway in the suburbs of a large city and from four schools in more rural parts of Norway. This was done in order to simulate the variation in places of residence within the CI group, which included participants from across Norway.

\subsubsection{Procedure}

For the children in the CI group, the test procedure was the same as previously described in paper I (see page 40).

For children in the NH group, all testing was completed at their schools. The battery of tests lasted for approximately 15 minutes and was completed individually in a separate room with the test administrator present, during regular school hours. At the end of the test sessions, children in the NH group were allowed to select one toy, as a thank you for participating. These toys were slightly more expensive than the small toys given the children in the CI, as the children in this $\mathrm{NH}$ group did not receive movie tickets and were not included in the drawing for an iPad.

\subsection{Sample in paper III}

The study sample initially included 135 children: one group of 45 children with HAs ( 21 boys, $47 \%$ ) (see box 9, figure 1) and one group of 90 children with normal hearing and typical development (39 boys, $43 \%$ ). The NH group was the same as previously described in paper I, (see page 38 and box 6, figure 1), with one exception: an additional 10 children were tested and included in the $\mathrm{NH}$ group. 
Because the NH group had twice as many participants as the HA group, a propensitymatching procedure was used to match NH group participants to HA group participants based on the following variables: chronological age, gender, nonverbal IQ, and SES (mother's and father's education). Thus, the final sample that was used for statistical analysis in the paper consisted of 45 children with HAs and 43 children with normal hearing. The mean age for children in the HA group was 105 months (range 66.5 - 152.9), while in the NH group, it was 111 months (range 68.1 - 158.8) at time of testing. Both groups had a nonverbal IQs in the normal range.

In the HA group, $37(\mathrm{n}=37,82.2 \%)$ children had moderate hearing loss and $8(\mathrm{n}=8$, $17.8 \%$ ) had severe hearing loss, measured at pure tone average (PTA) across four frequencies $(500,1000,2000$ and $4000 \mathrm{~Hz})$ in the better ear. The majority $(\mathrm{n}=32,71.1 \%)$ of the children were diagnosed with a hearing loss at birth, though some $(n=4,8.9 \%)$ were diagnosed during the first 12 months after birth, and $9(n=9,29.0 \%)$ children were identified after 12 months of age. The average age at diagnosis was 8.7 months, ranging from diagnosis at birth up to 81 months. Most children $(n=39,86.7 \%)$ reported using their HAs during all waking hours, while 4 ( $8.9 \%$ ) children used their HAs all day, but with some breaks. Two children (4.4\%) used their HAs for 4-8 hours a day.

\subsubsection{Inclusion criteria}

Both groups were recruited using the same inclusion criteria as described in paper I, see page 38. The HA group had one additional inclusion criteria: congenital or early acquired bilateral moderate to severe hearing loss that required treatment with amplification.

\subsubsection{Recruitment of children with HAs}

Unlike for children using CIs, there is no national registry of children with HAs, and they receive follow-up care at local ENT departments. To recruit children with HAs, project researchers collaborated with ENT departments in southern, western, mid- and northern parts of Norway. The ENT departments were given the inclusion criteria, and they extended invitations to participate to children and parents in their regions who fulfilled these criteria. Signed consent forms returned by parents to the ENT departments were passed on to project staff. Research assistants in the project then contacted the parents directly and set up times for participation at their local ENT department. 


\subsubsection{Recruitment of children with $\mathrm{NH}$}

The process to recruit children to the NH group is described on page 39.

\subsubsection{Procedure}

Children in the HA group were tested either at their local ENT departments or at the CI unit, if they lived in close proximity to Oslo. Children and their parents were offered the opportunity to have their children's HAs checked at their local ENT department in conjunction with testing in the project. The NH group were tested at their schools, at home or at the CI unit.

Both groups of children were tested with a battery of test, following the procedure which is described in the outline of paper I, on page 40 .

\subsection{Materials}

Children who participated in the project completed a battery of tests that assessed various aspects of language and cognition, and both the children themselves and their parents completed questionnaires on HR-QOL and communication. A description of the HR-QOL questionnaire can be found in chapter 3.6.3, on page 50 .

Nonverbal IQ was assessed for all children in the three papers, with the exception those in the NH group in paper II, using Raven's Progressive Matrices (Raven, 2004, 2008) The Raven test can be administered with very simple instructions and is often used in groups with language or communication impairments.

Language skills were examined through two different tests as well as a questionnaire. In paper I, the children in the CI group were tested using the British Picture Vocabulary Scale - Second Edition (BPVS-II) (Dunn, Dunn, Whetton, \& Berley, 1997) and the Clinical Evaluation of Language Fundamentals (CELF-4) (Semel, Wiig, \& Secord, 2003). In paper II, only scores on the CELF-4 were reported. The PBVS-II measures receptive vocabulary; participants are asked to pick one out of four pictures that corresponds to a target word. The CELF-4 is a comprehensive language test with 13 different subtests that produce scores for seven indexes: core language, receptive language, expressive language, language content, language structure, language memory and working memory. In paper III, language was not directly assessed, but parents assessed and reported their children's communication skills using the Children's Communication Checklist, Second Edition (CCC-2) (Bishop, 2011). This 
questionnaire consists of 70 questions that assess structural, nonverbal and pragmatic aspects of language.

Hearing was measured differently across the three papers. In papers I and II, children's hearing was reported as the percentage correct answers given on the Phonetically Balanced Word List (Øygarden, 2009). In addition, in paper I, children also completed the Norwegian Hearing In Noise Test for children (HINT); scores for sentence perception in quiet conditions were reported as the percentage of correct responses given, and for sentence perception administered in noisy conditions the sound-noise ratio was reported (Myhrum, Tvete, Heldahl, Moen, \& Soli, 2016). In paper I, parents' answers to selected questions from the Speech, Spatial and Qualities of Hearing Scale (Gatehouse \& Noble, 2004) were combined into index scores of everyday hearing. In paper III, hearing was measured as PTA across the frequencies 500, 1000, 2000 and $4000 \mathrm{~Hz}$, as well as the signal-to-noise ratio reported from HINT.

\subsection{Statistical analysis}

The variables used to assess HR-QOL across the three papers mostly violated the assumption of normal distribution when assessed through both statistically with the Kolmogorov-Smirnov analysis of normal distribution, and by visual inspection of the data. The HR-QOL data rather showed a clear skewness towards the higher end of the scale, indicating more children with good HR-QOL than poor. This is not uncommon in research measuring HR-QOL. Many of the scales used to assess QOL were initially developed to assess the impact of illness. But, if the individuals participating are, for most part, healthy, there is a risk of a slight ceiling effect, with many individuals indicating few problems (Fayers \& Machin, 2007, p. 275). This result was seen in the current study. To compensate for data that did not follow normal distribution, data was analyzed using appropriate nonparametric statistical tests when necessary.

\subsubsection{Paper I}

In paper I, there were two main research objectives. The first objective was to compare mean/median scores on proxy-reported HR-QOL in a group of children with CIs to those of a group of children with normal hearing. This was done by applying the nonparametric alternative to the Student's t-test, the Mann-Whitney U test. The second 
objective was to explore the associations between the overall HR-QOL and the individual variables thought to be related to higher or lower scores of HR-QOL. For this second research objective, the nonparametric Spearman correlations were applied. The alpha level chosen to determine statistical significance for the statistical analysis was 0.05 .

In addition, to assess the reliability of the HR-QOL measure, a Cronbach's alpha was calculated for each subscale, for both groups combined and for each separate group. A Cronbach's alpha over 0.7 is considered sufficient (Field, 2013, p. 709). The Cronbach's alpha level was found to be acceptable: 0.86 for the groups combined, and 0.89 for each group individually. The intercorrelation between different subscales within the questionnaire were moderate to high and ranged in magnitude from 0.412 , between school functioning and emotional functioning, to 0.671 , between school functioning and social functioning. This suggest that although the different subscales are intended to measure different aspects of HRQOL, they also overlap. The intercorrelation is similar to what is reported in the validation of the questionnaire in adolescents (Reinfjell, Diseth, Veenstra, \& Vikan, 2006).

\subsubsection{Paper II}

For paper II, there were three different research objectives. As in paper I, the first was to compare the mean/median of self-reported HR-QOL between children using CIs and children with no hearing loss, matched based on chronological age and gender. As the groups were matched, they were compared using a Wilcoxon matched-pairs sign-rank test. For the second research question, parent-reported and self-reported HR-QOL, in the CI group only, were compared. A Wilcoxon matched-pair sign-rank test was used to examine possible differences in reporting at the group level, while an intraclass correlation coefficient (ICC) (two-way mixed effect absolute agreement single measure) was calculated to evaluate the agreement between child and parent. A visual representation, in the form of a Bland-Altman plot, was created to examine possible tendencies for systematic differences in parent-proxy or self-report, though no systematic pattern emerged. For the third research question, possible individual factors associated with higher or lower scores on HR-QOL were examined using single univariate regression analysis. If variables in the univariate linear regression had a significance level below 0.20 , they were entered into a multivariate regression analysis (Maldonado \& Greenland, 1993). 


\subsubsection{Paper III}

In the third paper, the main object was to compare parent-reported communication and parent-proxy-reported HR-QOL in a group of children using HAs to those in a group of normal hearing and typically developing peers. The initial groups of children using HAs $(\mathrm{n}=45)$ and children with normal hearing and typical development $(\mathrm{n}=90)$, were different in number. A procedure of propensity matching was performed in order to balance the control and clinical groups based on important contextual variables: chronological age, gender, nonverbal IQ, and SES (mothers' and fathers' education levels). After matching, the groups consisted of 45 children using HAs and 43 children with normal hearing and typical development.

For the first research question, how parents rated communication, the total score from each group were compared using a Mann-Whitney U test. To further assess differences and identify possible language difficulties, a descriptive approach was chosen. When comparing groups on HR-QOL, the different subscales in the questionnaire were intercorrelated. Therefore, the groups were compared using logistic regression. To examine which factors were associated with parent-reported communication skills and HR-QOL in the HA group only, a series of single univariate regression analyses was performed.

\subsection{Issues of validity}

This thesis has two major concepts or constructs that it aimed to measure and make inferences about: children with hearing loss and quality of life. For a concept to be studied, it needs to be operationalized, or defined in a way that makes it possible to measure. How well one is able to operationalize a concept to accurately reflect its meaning as it is used in theory and language affects the study's construct validity. This is important, as the goal of most research, including that of this thesis, is to make inferences and to generalize the results to a higher-order theoretical construct, and eventually, to everyday life (Shadish, Cook, \& Campbell, 2002, pp. 65-66). In addition, when comparing clinical groups to groups representing typically developing counterparts, the representativeness of the typically developing sample is important for the validity of the conclusion. 


\subsubsection{Choice of inclusion criteria and consequences for construct- and external validity}

For papers I and II, the children with CIs who participated in the project initially represented over $80 \%$ of the population of children with CIs in this particular age group. Including the entire sample of participating children would thus provide a very representative overview of that population. However, as previously discussed, children with hearing loss are not a homogenous group of children, and previous research was not able to draw firm conclusion. For example, in their review of the literature, Lin \& Niparko (2006) suggested future studies employ more clear inclusion criteria to ensure more homogenous samples. In addition, research on QOL in this particular group is inconsistent, and completed reviews suggested a need for articles that focus on more well-defined groups. Because of the high degree of heterogeneity and the presence of several confounding variables, the effect of hearing loss on QOL is challenging to examine. The literature suggests that approximately $30-40 \%$ of children with hearing loss have additional disabilities or conditions that coincide with their hearing loss (Birman, Elliott, \& Gibson, 2012; Edwards, 2007; Fortnum, Marshall, \& Summerfield, 2002). This estimate corresponds well with the samples in papers I and II, for which approximately $50 \%$ of the children were excluded due to either the presence of additional disabilities or conditions or the fact that their first language was not a Scandinavian language. Thus, although the use of the inclusion criteria resulted in almost $50 \%$ of the children in the relevant age group being excluded, their use also led to a more well-defined group than simply controlling for variables would have provided. The remaining group of children may be considered representative of children with CIs in Norway who have typical development apart from hearing loss though not representative of all children with hearing loss.

Paper III, on children with HAs, has similar limitation for its generalizability. We employed the same inclusion criteria in paper III as in papers I and II. Children using HAs receive follow up at local ENT departments in the areas where they live. It was therefore difficult to determine how many children had received HAs and which ENT departments were treating children who fulfilled the inclusion criteria. This is in contrast to the situation with children using CIs, as all children with CIs are treated at the same hospital. This made recruiting children using HAs more demanding, and it also makes it harder to determine how representative the current sample of children with HAs is of children with HAs in Norway in general. Relatively few studies have been conducted including this population in Norway, and 
the population is thus less known prior to the current study. The inclusion criteria used in this study affect the generalizability of outcomes, and the study should be understood as describing outcomes in a specific subgroup of children, not necessarily as applicable to all children using HAs in Norway.

Although some limitations are present, having the same inclusion criteria across the three papers is foremost a strength. It gives a more detailed picture for a particular subgroup of children who have a hearing loss, and gives a foundation for future studies of other specific subgroups.

\subsubsection{Children with typical development and normal hearing: external validity}

However, it is not only the clinical samples of children that may have challenges for generalization. Two groups of children with normal hearing were recruited for the project to match the groups of children with hearing loss. The first group of children with normal hearing were recruited through research assistants' networks, as well as from randomly selected schools in rural and urban parts of eastern Norway. Parents of children with normal hearing in paper I reported very few problems, particularly when reporting on social functions. Nearly $55 \%$ of parents in the NH group reported that their children never experienced any difficulties in social functioning. This is very high, compared to both the American norming sample (Varni, Limbers, \& Burwinkle, 2007) and the Norwegian validation of the questionnaire in adolescents (Reinfjell et al., 2006). The NH group and CI group in paper I also differed somewhat in SES, with $63 \%$ of mothers of children with CIs having completed at least one year of college education, compared to $84 \%$ of mothers of children with normal hearing. The children were recruited to match the age and gender distribution in the CI group, but not necessarily to be representative of the general population of children in Norway, as were comparison groups used in other clinical studies of children with disabilities.

In paper II, children in the NH group were recruited from one urban and four rural schools, which reflected the living situations of the children with CIs, who live in all areas of Norway. The children were recruited to individually match the ages (+/- 6 months of the child with CIs age) and genders of the children in the CI group who had completed the self-reported HR-QOL questionnaires. Participants in this group were similar to those in the CI group on SES, measured as mothers' educational levels, with $65 \%$ of mothers in the CI group having some higher education compared to $72 \%$ in the $\mathrm{NH}$ group. 


\subsubsection{Choosing HR-QOL measurement and consequences for construct validity}

QOL, or HR-QOL, is not a concept that is easy to define clearly, and there is wide variation in how QOL is defined and measured. To avoid confusion about what this study measures, we included a section in each paper explaining the concept of QOL and its specific use in the current study. We relied on the definition of QOL provided by the WHO, which is also the definition underlying the development of the questionnaire used for QOL assessment, PedsQL (Varni, Burwinkle, Seid, \& Skarr, 2003).

The PedsQL has been found to be a valid and reliable tool for assessing QOL in children (Varni et al., 2003; Varni, Seid, \& Kurtin, 2001). The PedsQL questionnaire is generic and consists of 23 questions that assess four domains: physical health, emotional functioning, social functioning, and school functioning. The questionnaire also provides two index scores: a total score (all questions) and a psychosocial health score (questions on emotional, social and school functioning). Questions in the questionnaire have been adapted to the cognitive and linguistic level of children in different age groups and allow for collecting both self- and proxy-reports of QOL (Varni et al., 2001). The questionnaire was translated into Norwegian, as were all parallel forms designed for different age. The questionnaire has been found to be valid and reliable for use in Norwegian for adolescents (Reinfjell et al., 2006), though it has not been validated for use in the current age group.

As hearing loss particularly affects communication, it was important to have a measure of QOL that included more than merely health status in the definition of HR-QOL. The PedsQL questionnaire includes, in addition to physical health, emotional, social and school functioning (Varni et al., 2001), and may thus be more sensitive to the issues possibly experienced by children with hearing loss. The use of the PedsQL was previously suggested by Lin \& Niparko (2006) and is one of the more commonly used tools in this population (Roland et al., 2016).

In the literature review by Roland et al. (2016), the authors point out that the PedsQL only moderately correlates with the hearing specific measure HEAR-QL (Rachakonda et al., 2014; Umansky et al., 2011). However, the choice of a generic questionnaire over a condition-specific questionnaire for the current project was deliberate. When conducting research among native speakers of a less widely used language such as Norwegian, there are fewer assessment tools available. Few questionnaires assessing QOL for children in general had been validated in Norwegian, and no condition-specific questionnaires had been 
translated or validated. Furthermore, the overall goal of the project was to examine the outcomes and identify measures that could improve outcomes in individuals who received CIs as children in Norway. It was thus considered important to highlight differences in functioning, as this would help identify areas for which better services are needed.

Although self-reporting is generally recommended for assessing QOL (Fayers \& Machin, 2007), children with hearing loss often have language difficulties and may not be capable of self-reporting at the same age as typically developing peers, as was experienced empirically in the current project. The initial plan was to collect self-reports from all children four years old and older. However, we quickly learned that this would not be possible for the vast majority of included children. Very few children had the language abilities necessary, even when provided visual support in order to conceptualize answer options (Likert scales with smiley faces). We therefor decided to collect self-reports from children six years old and older. Still, when we analyzed the data for paper II, we found the average age at testing was approximately one year older for self-reports than for parent-reports for the same group because 22 of the children were unable to complete the self-report, due to difficulties with understanding the questions among the younger children. The mean language score in the CI group reported in paper II is a standard score of 73.9 (range 40-114, SD 18.3). This score suggests that many children in the CI group have language skills that are inferior to those of their peers, even though the mean score includes only the children with strong enough language skills to self-report. Papers I and III, rely on parent-proxy reporting only, and although this, in some respects, may reduce the validity of the measurement of QOL, it still offers a valuable perspective. The use of parent-proxy reports may, in these cases, provide valuable information and allows inclusion of a broader range of children. In addition, the use of parent-reports limits the number of tests children have to complete and offers a gentle way of gathering information. Finally, parents' perceptions of how their children are doing are important factors in whether they seek professional help within the healthcare or the educational systems.

\subsection{Ethical considerations}

The project from which the data underlying the articles in this thesis were taken was approved by the regional committees for medical and health research ethics, as well as the data protection officer at OUS prior to data collection (REK number 2012-2154) (Regionale 
komiteer for medisinsk og helsefaglig forskningsetikk, n.d.). All collected data was stored in locked filing cabinets, accessible only to project employees. Digitalized versions with traceable IDs used for statistical analyses were stored in OUS Rikshospitalet's own secure data storage, as well as UIO's own storage option: service for sensitive data (TSD). TSD is accessible from off campus and allows researchers on the same project to share updated data files. The service follows Norwegian privacy regulations, which researchers at UIO are also committed to following (Service for Sensitive Data, 2019).

\subsubsection{Small population}

As children who have hearing loss constitute a small group, we were careful not to provide too much detailed information about participants and results to avoid recognition. Even if children could identify themselves as included, given the inclusion criteria, data that is analyzed quantitatively produces results represented as means, rather than single scores, meaning no individual child could be recognized in the final results.

\subsubsection{Children in research, weariness of testing and reward for participating}

Research including children, and especially children with special needs, must consider how to best protect the participating children. When calling parents in advance to ask whether they and their children would like to participate in the project, we encouraged parents to talk to their children about participation and consider their children's opinions. Included with the letter inviting them to participate, there was an information sheet for the parents, and a shorter version adapted to the child's age. However, the final decision on participation was legally made by each child's parents, because of the children's ages (Den nasjonale forskningsetiske komité for samfunnsvitenskap og humaniora, 2016). Some children found the testing boring, and some of the older children in particular expressed weariness of testing in general. Many of the children, especially those using CIs, had likely participated in a number of research studies over the years in addition to evaluations of language or cognition done in school or by educational psychologists. Test administrators aimed to make the test sessions as enjoyable as possible by providing the children with regular breaks, including for lunch, and offering encouragement and praise for their endurance, as well as by rewarding them with stickers or small toys, such as bouncy balls or balloons, after completion of the different tasks. The children did not know in advance that they would receive these small gifts during the test sessions. At the end of the test session, each child received two gift cards for cinema tickets 
that could be used all over Norway. They were also informed that they were part of a lottery for an iPad, through which a winner was selected every six months from among the participants during those months.

Ethical guidelines for medical research in Norway recommend that rewards for participation, especially if the project is offering actual money for participation, should not to be so large as to threaten the principle of volunteerism or cause participants to overlook potential risks of participation (Den nasjonale forskningsetiske komité for medisin og helsefag, 2009). However, as parents made the final decisions on participation, it is unlikely their motivation for participation was the movie tickets their children would receive. Parents generally expressed recognition that their children's participation might not result in any immediate reward but were motivated by the fact that by sharing their experiences. They were contributing to results of a study that might help future children who receive hearing amplification. In addition, their participation at this time might highlight issues that that could be addressed though improvements in services, benefiting their own children in the future. With this backdrop, it may be assumed that the gifts merely contributed to the children's wellbeing during test sessions and served as thank yous to the children for participating in the study.

Another issue related to volunteerism in research is data collection in clinics where the participants are patients. It is generally recommended that patients be included with caution, as some may feel obligated to participate if asked to do so by a person who is involved in their treatment (Den nasjonale forskningsetiske komité for medisin og helsefag, 2009). In the current project, the information sheet clearly stated that participation was voluntary and that declining to participate would have no effect on their treatment at the clinic. Although the current research project was carried out in the clinic's facilities, researchers working in the project were not clinicians and had no prior relation to the participants. This was a conscious choice to further strengthen the separation between the research project and clinical staff.

\subsubsection{HR-QOL as a sensitive research topic}

HR-QOL is a highly subjective measure and may be a sensitive topic to assess. A low score on a QOL measure generally indicates that the individual is not doing well physically, mentally or socially. When including this measure in research, it is important to consider what this score can tell us. At the same time, the HR-QOL questionnaire used in the current study is not a diagnostic tool, and no standard scores or norms exist. QOL measures may work well 
in research settings, but interpretation on an individual level in a test session may be more challenging (Fayers \& Machin, 2007). As all children completed the questionnaires without their parents present, children may have reported problems that their parents were unaware of. In cases where it was evident the child clearly struggled; test administrators informed the project leader. The project leader then consulted with clinicians working in the CI unit who had followed the child for several years, to confirm that the issue in question was being addressed through the local health care system. If the issue had not taken addressed, and a concern remained, the parents were informed. 


\section{Summary of Studies and Main Findings}

\subsection{Paper I}

Purpose: The study compared how parents of children with cochlear implants (CIs) and parents of children with normal hearing perceive their children's health-related quality of life (HR-QOL).

Method: The sample consisted of 186 Norwegian-speaking children in the age span of 5;0-12;11 (years;months): 106 children with CIs (53\% boys, $47 \%$ girls) and 80 children with normal hearing ( $44 \%$ boys, $56 \%$ girls). No children had known additional disabilities affecting language, cognitive development, or HR-QOL. Parents completed the generic questionnaire Pediatric Quality of Life Inventory (Varni, Seid, \& Kurtin, 2001), whereas children completed a test battery measuring different aspects of language and hearing.

Results: Parents of children with CIs reported statistically significantly poorer HRQOL in their children, on Pediatric Quality of Life Inventory total score and the subdomains social functioning and school functioning. Roughly $50 \%$ of parents of children with CIs reported HR-QOL levels (total score) within normal limits. No significant differences between groups emerged on the physical health and emotional functioning subscales. For the children in the group with CIs, better speech perception in everyday situations was associated with higher proxy-ratings of HR-QOL. Better spoken language skills were weakly to moderately associated with higher HR-QOL.

Conclusions: The findings suggest that the social and school situation is not yet resolved satisfactorily for children with CIs. Habilitation focusing on spoken language skills and better sound environment may improve social interactions with peers and overall school functioning.

\subsection{Paper II}

Objectives: The objective of this study was to assess self-reported health-related quality of life (HR-QOL) in a group of children with cochlear implants (CIs) and to compare their scores to age- and gender- matched controls. The authors also assessed the agreement between proxy- and self-reported HR-QOL in the CI group and examined individual and 
environmental variables that could be associated with higher or lower self-reported HR-QOL in the CI group.

Design: The sample consisted of 168 children between the ages of 5;6 and 13;1 (years;months), where 84 children had CIs (CI group) and 84 were age- and gender-matched controls with normal hearing (NH group). HR-QOL was assessed with the generic questionnaire Pediatric Quality of Life Inventory. Parents of the children in the CI group completed the same questionnaire as the children. In addition, the children in the CI group completed tests of language, hearing, and nonverbal I.Q. and background variables such as age at implantation and socioeconomic status were assessed.

Results: On average, children with CIs rated their HR-QOL lower than peers with normal hearing on school functioning, social functioning, and overall HR-QOL. A higher percentage of children with CIs reported low levels of HR-QOL than did those in the NH group, $27 \%$ and $12 \%$, respectively. The differences between groups were small, and fewer children than parents reported concerningly low HR-QOLs. Better spoken language skills and older age at the time of testing was associated with better HR-QOL.

Conclusions: Most children with CIs in this study reported HR-QOLs that were close to those of their age- and gender-matched normal-hearing peers. The children, however, reported concerns about social and school functioning, indicating that these areas require more attention to ensure children with CIs have good HR-QOL. Improving spoken-language skills in children with CIs may contribute to improved HR-QOL.

\subsection{Paper III}

Purpose: The study compared parent-reported communication abilities and healthrelated quality of life (HR-QOL) in children using hearing aids (HAs) to that of normalhearing peers. Predictors of communication abilities and HR-QOL were assessed in the HA group.

Method: Eighty-eight children between the ages of 5;6 and 13:1 (years; months) and their parents participated: 45 (21 male) children with bilateral moderate to severe hearing loss using HAs, who had no additional disabilities, were included, and a group of 43 children (20 male) with normal hearing and typical development were matched with the HA group based on age, gender, nonverbal abilities and SES. Parents completed questionnaires on 
communication skills (including speech, structural language and pragmatics) and HR-QOL (including physical health, emotional functioning, social functioning and school functioning).

Results: The HA group reported statistically significantly poorer overall communication abilities and HR-QOL than did the NH group. Parents of half of the children with HAs reported their children had language difficulties, indicating a need for further clinical assessment. In terms of HR-QOL, differences on school functioning scores accounted for the majority of the difference between the overall group scores. Better parent-reported communication abilities were associated with better parent-reported HR-QOL in children using HAs.

Conclusion: A substantial proportion of children with HAs, even those without additional disabilities, struggle with communication, and some experience lower schoolrelated HR-QOL than their peers. These findings suggest that more follow up may be needed for children with HAs to close the gap to their peers, especially with regards to communication. 


\section{Discussion of Main Findings}

The purpose of the present thesis was to examine HR-QOL in 5-12-year-old children with different degrees of bilateral hearing loss treated with an amplification device, with otherwise typical development. An additional goal of the thesis was to investigate whether better language or communication skills were associated with higher or lower HR-QOL in children with hearing loss. In each of the three papers, factors previously found to be associated with QOL or psychosocial issues, such as age at implantation or diagnosis, chronological age, nonverbal abilities or socioeconomic status, were examined.

The ultimate goal of interventions for children who have a hearing loss, regardless of the degree, is to enable them to develop hearing, spoken language and QOL that match those of their hearing peers. The results of the currents papers are, in this regard, at least partly encouraging. A majority of children and parents perceived the children's HR-QOL to be within the normal range. Still, even in a group of children with typical development apart from their hearing loss, lower levels of QOL were reported with regards to social and school functioning, compared to those reported for their peers.

\subsection{HR-QOL in children with hearing loss}

All three papers indicated that areas of HR-QOL such as physical health and emotional functioning were unaffected in children with hearing loss. This is a very positive finding, considering that emotional functioning is the factor most closely associated with other aspects of mental health, and it stands in contrast to several previous studies that found increased emotional and behavioral difficulties in children with hearing loss (Fellinger, Holzinger, Sattel, et al., 2009; Stevenson et al., 2015; Theunissen et al., 2011; Theunissen et al., 2014; Theunissen et al., 2015). A major difference between children with hearing loss and their peers normal hearing seems to be connected to differences in well-being in the social and school domain. This difference is apparent in reports from both parents of children with CIs and reports from the children themselves. Parents of children using HAs report difficulties with school functioning. According to paper II, parents of children with CIs report more difficulties than do the children themselves.

The findings of the present papers align well with those of previous research, in that there is no simple and clear conclusion regarding HR-QOL in children with hearing loss. 
Rather, it seems that some subdomains, such as social and school functioning, are affected while other areas, such as physical health and emotional functioning, are not (Roland et al., 2016).

Scores for HR-QOL were not statistically compared between children using HAs and children using CIs. However, a descriptive examination of scores suggests the two groups are fairly similar. The median total score on the proxy-reported PedsQL was 80.44 in the CI group and 80.43 in the HA group. There were some differences across the subdomains, with the largest being in school functioning, where the median score of HA group was five points higher than that of the CI group. This suggest that regardless of the type of amplification devise or degree of hearing loss, these children experience more difficulties than do their peers with normal hearing and typical development and may need additional adjustments in school.

Differences in school functioning indicate the need for future follow up and additional research. The current papers did not investigate which areas of the school day children and parents perceive to be challenging. However, several adjustments that are included in the recommendations for teaching Norwegian students who have hearing loss are relevant here: reduced number of students in classes, predictability through the use of schedules that include overviews of both the day and week, acoustically adjusted classrooms, the use of microphones, and general actions to reduce noise (Utdanningsdirektoratet, 2009). In a descriptive survey of school environments for students with a hearing loss in Norway, Hendar (2012) found that many students were taught in classrooms that were not acoustically adapted, and many did not have access to technical equipment in class. Hendar concluded that too few schools had adequate facilities for teaching students with hearing loss given that a functional sound environment is a prerequisite for participation for all students with hearing loss (Hendar, 2012, p. 69). The participants in the current papers, however, seemed to have access to some adaptation during their school day. Among the parents of children in the CI group, $92(87 \%)$ reported that their children had access to technical equipment in school and $71(67 \%)$ indicated that reduced group size was used for at least some hours during the week. In the HA group, 42 (93\%) reported access to technical equipment, and 15 (33\%) reported that reduced group size was used for at least some hours during the week. Still, these adjustments may not be sufficient to offer the children full opportunity for participation. Inadequate school accommodations may also be reflected in the lower scores on the social subdomain of QOL reported by children with CIs and their parents. Much of the school day is 
spent in noisy environments, and during less structured sessions or recess, technical equipment may not be available. Problems with speech perception in noise has previously been associated with risk of social isolation among children with hearing loss (Huber, Burger, et al., 2015). Paper I showed an association between better hearing in noise and better parentreported HR-QOL, and better parent-reported hearing in everyday situations was weakly to moderately associated with better parent-reported HR-QOL. In paper III, however, no association with hearing in noise was found. The hearing in noise measure is assessed in a formal test environment and may not fully capture the challenges in real life. The current papers do not provide a clear conclusion as to whether everyday hearing in noise is a factor affecting well-being socially and in school for children with hearing loss. Few other studies have investigated whether hearing in noise affects QOL, and further research is needed in this area (Huber \& Havas, 2019).

An overall conclusion common to the three papers was that children with hearing loss have more difficulties with school functioning, and children with CIs also have more difficulties in the social domain. The differences between children with hearing loss and children with normal hearing in these subdomains are not large, but they still indicate a need further action to provide this group of children with the same opportunities for experiencing good QOL as their peers. The children in the current papers did not report difficulties associated with mental health outcomes, which is a positive finding. Future studies should focus more on which aspects of school functioning need intervention in order to improve children's well-being in school. As children themselves tend to report fewer problems associated with QOL than their parents do, it is important to collect reports from both children and parents when assessing OQL.

\subsection{Factors associated with higher or lower HR-QOL}

In order to provide better interventions in the future, a subgoal of the three papers was to examine additional factors that may be associated with higher or lower ratings of HR-QOL. In contrast to a number of other studies, we found no association between age at implantation or diagnosis, nonverbal IQ, or SES in any of the papers. One reason for this may be that the inclusion criteria applied in the three papers reduced the variation on factors previously found to be of importance for QOL. For example, $90 \%$ of children in the CI group who were prelingually deaf received their implants before the age of three (mean 20.78, range 5.49- 
53.26). In contrast, was the mean age at implantation was 5.83 years in the study by Loy et al. (2010) that found an effect from earlier implantation on QOL.

Another main finding common to the three papers was the association between better reported HR-QOL and better spoken language or communication skills. This suggests that, for children integrated into mainstream schools, which includes the majority of the sample, language and communication abilities are important for well-being, both socially and academically. Children with hearing loss struggle more with communication and spoken language skills than do their normal-hearing peers. This difficulty was evident despite the fact that most of the participating children were pupils in mainstream schools and that, for children in the CI group, identification of hearing loss and implantation with bilateral stimulation occurred prior to three years of age. Children with CIs who were tested on CELF $(n=88)$ had a mean core score equal to 72 SS (range 40-114, SD 18.9). Statistically, $16 \%$ of children are expected to have a language score more than 1 SD below mean, but in the current sample $72 \%$ of children with CIs had language scores more than 1 SD below the normative mean of $100 \mathrm{SS}$. For children using HAs, half of the parents reported communications skills that would require more testing to exclude possible communication disorders. Although the variation in scores within both groups was large, and certainly not all children struggled with poor language skills, the results were still far below the ideal of being on par with their normal-hearing peers.

It is important to note that almost all of children with CIs were born before universal hearing screening was an established practice at every hospital in Norway. This may have delayed diagnosis for some children. In addition, we have limited knowledge as to the type amount of help the children received after diagnosis of hearing loss. In the HA group, more than half of parents reported that they never, or almost never, received guidance on how to support their children's language development in the first years after diagnosis. This is not in line with the 1-3-6-recommendations from the JCIH (Joint Committe on Infant Hearing, 2019; Joint Committee on Infant Hearing, 2007), and is not in line with the current knowledge of a sensitive period for auditory stimulation (Sharma et al., 2015; Sharma et al., 2002).

Although the current papers are predominately descriptive and may not make firm conclusions, the results suggest that more could be done at earlier ages. Children identified with hearing loss at newborn screenings are known to be at higher risk for delayed language and problems with psychosocial functioning. Providing family-centered interventions aimed at strengthening spoken language and socioemotional development in children with hearing 
loss, regardless of degree of hearing loss and type of amplification device, could work to prevent many difficulties. The current knowledge of best-practice cannot guarantee every child with hearing loss language skill within the normal range. However, some studies suggest better results are possible (Fulcher et al., 2012).

Effective mastery of the communication form used in the child's environment has previously been found to be of importance to socioemotional well-being. Just as early critics of CIs voiced concerns for children's QOL if they did not become part of a sign language or Deaf community, a similar concern may be voiced today for children who are not afforded the ability to master verbal communication. Most children with CIs in the current studies, were integrated in mainstream schools $(86 \%)$, while all the children using HAs were integrated in mainstream school. Furthermore, all children used spoken Norwegian to a greater or lesser degree. In the CI group, $85 \%$ of parents report that the family used spoken language only or spoken language with occasional sign support, while the remaining $15 \%$ reported using either a higher level of sign support or a combination of different communication modes. Among the children using HAs, $8 \%$ of parents reported the family used a combination of different language modes, while the remaining $92 \%$ used spoken language only or spoken language with occasional sign support. In order for children with hearing loss to have a sense of belonging to their parents' and environments' language communities, it is important for them to have good spoken language skills. The results of the current thesis suggest that this affects their overall QOL, especially in school settings.

One of the challenges in ensuring adequate follow up for Norwegian children with hearing loss is that although families and children have the right to receive help in their municipalities to support language development, the type and degree of help available varies widely. This results in local and regional differences in follow-up care, where some families and children receive very good help, while others do not receive enough. Among parents of children using CIs, $23 \%$ reported that they did not receive follow up, besides technical follow up, on how to support their child hearing or language development during the first years after diagnosis of hearing loss. Half of parents of children using HAs reported the same. This is concerning, given the percentage of children who struggle with language. The numbers are based on parent-reports and may be biased by inaccurate memories of early development. There is also a possibility that some children did not receive follow up because they were already following typical developmental trajectories and did not need additional help related to language development. This should be addressed further in future studies. 


\section{Limitations}

Though the number of participants in the three papers made up relatively large samples compared to those previously published studies, the overall number still limited the types of statistical analysis that were appropriate. In addition, the project as a whole was a cross-sectional study, which affects what inferences could be made based on the applied analyses. The study design of the three papers did not allow for conclusions on causality. The observed associations between HR-QOL and language are plausible and may be part of an explanation, but we cannot conclusively state whether language difficulties cause lower HRQOL in children with hearing loss. There may be other underlying variables, such as factors related to the etiology of the hearing loss, that were not controlled for in this study and could cause, or at least mediate, the observed association. It is possible that some of the variation in both language and HR-QOL may be related to underlying genetic causes or conditions that both affect overall cognition and cause hearing loss. For many children in the current papers, the etiology of their hearing loss was not known. Future studies may take advantage of earlier detection and possible better methods for detecting etiology. This may help to identify subgroups of children that need more help than others.

Furthermore, the applied inclusion criteria helped ensure more homogenous groups but also reduced the potential generalization of the conclusions. The results are not applicable to all children in Norway with hearing loss, but they provide a reasonable representation of a specific subgroup; children with hearing loss and otherwise typical development.

Another limitation related to generalization of results stems from the nature of the Norwegian healthcare system. It is not surprising that SES was significantly associated with HR-QOL outcomes in this sample. The Norwegian healthcare system is free for all inhabitants, and access to CIs and HAs is not dependent on family income. In addition, all children in Norway are offered bilateral implants as the standard procedure, unless there are medical contradictions, and treatment option is not universally available across the world.

Future studies should examine which areas of school functioning are presenting difficulties for children with hearing loss today and what strategies might be implemented in order to improve educational settings. Future studies also need to focus on the group of children who have more complex needs in addition to their hearing loss. This has previously been found to be a risk factor, and thus more knowledge is needed about how their QOL can 
Furthermore, additional information is needed to evaluate the impact of early family-centered interventions and their potential effects on long-term language development. 


\section{Conclusion}

A majority of children and parents perceive the children's HR-QOL to be within the normal range. Still, even in a group of children with typical development apart from their hearing loss, the children with CIs experience lower levels of QOL with regards to social and school functioning, and children with HAs in the school domain, compared to those of their peers. Better spoken language skills and better communication skills were associated with higher levels of HR-QOL. Median scores for spoken language skills and communication skills in the groups of children with hearing loss were below the normative mean. Intervention or follow up post diagnosis was not specifically investigated in the current papers, but a fifth of parents of children with CIs and more than half of parents of children using HAs, report that they did not receive non-technical follow up on how to support their children's language development during the first years after diagnosis of hearing loss. This is concerning given that early diagnosis of hearing loss in children, especially if congenital, allows early intervention, promoting more typical language development. Based on the findings in the current thesis, recommendations for future praxis are to use the advantages offered by early diagnosis to promote spoken language interventions in children with hearing loss. Improved spoken language skills seem not only to equip children to succeed academically but also be an important tool for improving overall HR-QOL. In addition, more knowledge is required to improve the follow up children receive in school. Combined, these strategies may be a step towards providing children with different degrees of hearing loss, educated in mainstream schools, with the same opportunities for well-being as their normal-hearing peers. 


\section{References}

Abdala, C., \& Keefe, D. H. (2012). Morphological and Functional Ear Development. In L. A. Werner, R. R. R. Fay, \& A. N. N. Popper (Eds.), Human Auditory Development (pp. 19-59). New York, NY: Springer.

André, F. E. (2003). Vaccinology: past achievements, present roadblocksand future promises. Vaccine, 21, 593-595.

Anmyr, L., Olsson, M., Larson, K., \& Freijd, A. (2011). Children with hearing impairment-living with cochlear implants or hearing aids. International Journal of Pediatric Otorhinolaryngology, 75(6), 844-849.

Armstrong, D., \& Caldwell, D. (2004). Origins of the Concept of Quality of Life in Health Care: A Rhetorical Solution to a Political Problem. Social Theory \& Health, 2, 361371.

Astington, J. W., \& Jenkins, J. M. (1999). A Longitudinal Study of the Relation Between Language and Theory-of-Mind Development. Developmental Psychology, 35(5), 1311-1320.

Bavelier, D., \& Neville, H. J. (2002). Cross-modal plasticity: Where and how? . Nature Reviews Neuroscience, 3, 443-452.

Birman, C. S., Elliott, E. J., \& Gibson, W. P. R. (2012). Pediatric Cochlear Implants: Additional Disabilities Prevalence, Risk Factors, and Effect on Language Outcomes. Otology \& Neurotology, 33, 1347-1352.

Boons, T., De Raeve, L., Langereis, M., Peeraer, L., Wouters, J., \& van Wieringen, A. (2013). Expressive vocabulary, morphology, syntax and narrative skills in profoundly deaf children after early cochlear implantation. Research in Developmental Disabilities, 34, 2008-2022.

Bornstein, M. H., Hahn, C.-S., \& Putnick, D. L. (2016). Stability of core language skills across the first decade of life in children at biological and social risk. Journal of Child Psychology \& Psychiatry, 57(12), 1434-1443. 
Carew, P., Mensah, F. K., Rance, G., Flynn, T., Poulakis, Z., \& Wake, M. (2018). Mildmoderate congenital hearing loss: secular trends in outcomes across four systems of detection. Child: Care, Health \& Development, 44(1), 71-82.

Ching, T. Y. (2015). Is Early Intervention Effective in Improving Spoken Language Outcomes of Children With Congenital Hearing Loss? American Journal of Audiology, 24(3), 345-348.

Ching, T. Y., Cupples, L., \& Marnane, V. (2019). Early cognitive predictors of 9-year-old spoken language in children with mild to severe hearing loss using hearing aids. Frontiers in Psychology, 10, 1-9.

Ching, T. Y., Dillon, H., Marnane, V., Hou, S., Day, J., Seeto, M., . . Yeh, A. (2013). Outcomes of early- and late-identified children at 3 years of age: findings from a prospective population-based study. Ear \& Hearing, 34(5), 535-552.

Cole, P. M., Armstrong, L. M., \& Pemberton, C. K. (2010). The role of language in the development of emotion regulation. In S. D. Calkins \& M. A. Bell (Eds.), Child Development. At the intersection of emotion and cognition. (pp. 59-78). Washington, DC American Psychological Association.

Conti-Ramsden, G., Mok, P. L. H., Pickles, A., \& Durkin, K. (2013). Adolescents with a history of specific language impairment (SLI): Strengths and difficulties in social, emotional and behavioral functioning. Research in Developmental Disabilities, 34, 4161-4169.

Crownson, M. G., Semenov, Y. R., Tucci, D. L., \& Niparko, J. (2017). Quality of Life and Cost-Effectiveness of Cochlear Implants: A Narrative Review. Audiology \& NeuroOtology, 22, 236-258.

Cummins, R. A. (2000). Objective and subjective quality of life: an interactive model. Social Indicators Research, 52, 55-72.

Cupples, L., Ching, T. Y., Button, L., Seeto, M., Zhang, V., Whitfield, J., . . Marnane, V. (2018). Spoken language and everyday functioning in 5- year-old children using hearing aids or cochlear implants. International Journal of Audiology, 57, 55-69. 
Dammeyer, J. (2009). Psychosocial development in a Danish population of children with cochlear implants and deaf and hard-of-hearing children. Journal of Deaf Studies and Deaf Education, 15(1), 50-58.

Davis, E., Waters, E., Mackinnon, A., Reddihough, D., Graham, H. K., Mehmet-Radji, O., \& Boyd, R. (2006). Paediatric quality of life instruments: a review of the impact of the conceptual framework on outcomes. Developmental Medicine \& Child Neurology, 48, 311-318.

Den nasjonale forskningsetiske komité for medisin og helsefag. (2009). Betaling til deltagere i medisinsk eller helsefaglig forskning. Retrieved from https://www.etikkom.no/forskningsetiske-retningslinjer/Medisin-og-helse/Betaling-tildeltakere-i-medisinsk-eller-helsefaglig-forskning/

Den nasjonale forskningsetiske komité for samfunnsvitenskap og humaniora. (2016). Forskningsetiske retningslinjer for samfunnsvitenskap, humaniora, juss og teologi. Oslo: De nasjonale forskningsetiske komiteene.

Dettman, S., Dowell, R., Choo, D., Arnott, W., Abrahams, Y., Davis, A., . . Briggs, R. J. (2016). Long-term Communication Outcomes for Children Receiving Cochlear Implants Younger Than 12 Months: A Multicenter Study. Otology \& Neurotology, 37, $82-95$.

Domellof, E., Hedlund, L., \& Odman, P. (2014). Health-related quality of life of children and adolescents with functional disabilities in a northern Swedish county. Quality of Life Research, 23(6), 1877-1882.

Duarte, I., Santos, C. C., Rego, G., \& Nunes, R. (2014). Health-related quality of life in children and adolescents with cochlear implants: self and proxy reports. Acta OtoLaryngologica, 134(9), 881-889.

Duarte, I., Santos, C. C., Rego, G., \& Nunes, R. (2016). School failure in students who are normal-hearing or deaf: with or without cochlear implants. SpringerPlus, 5(1), 1-8.

Dunn, L. M., Dunn, L. M., Whetton, C., \& Berley, J. (1997). The British Picture Vocabulary Scale II. Windsor GL Assessment. 
Edwards, L. (2007). Children with cochlear implants and complex needs: A review of outcome research and psychological practice. Jornal of Deaf Studies and Deaf Education, 12(3), 258-268.

Eggermont, J. J., \& Moore, J. K. (2012). Morphological and Functional Development of the Auditory Nervous System. In L. A. Werner, R. R. R. Fay, \& A. N. N. Popper (Eds.), Human Auditory Development (pp. 61-105). New York, NY: Springer.

Eiser, C., \& Jenney, M. (2007). Measuring quality of life. Arch Dis Child, 92, 348-350.

Emmett, S. D., \& Francis, H. W. (2015). The Socioeconomic Impact of Hearing Loss in US Adults. Otol Neurotol, 36(3), 545-550.

Fanshel, S., \& Bush, J. W. (1970). A health-status index and its application to health-services outcomes. Operations research, 18, 1021-1066.

Fayers, P. M., \& Machin, D. (2007). Quality of Life. The assessment, analysis and interpretation of patient-reported outcomes. Chichester: Wiley.

Feder, K. P., Michaud, D., McNamee, J., Fitzpatrick, E. M., Ramage-Morin, P., \& Beauregard, Y. (2017). Prevalence of Hearing Loss Among a Representative Sample of Canadian Children and Adolescents, 3 to 19 Years of Age. Ear \& Hearing, 38, 720.

Fellinger, J., Holzinger, D., Beitel, C., Laucht, M., \& Goldberg, D. (2009). The impact of language skills on mental health in teenagers with hearing impairments. Acta Psychiatrica Scandinavica, 120(2), 153-159.

Fellinger, J., Holzinger, D., Sattel, H., \& Laucht, M. (2008). Mental health and quality of life in deaf pupils. European Child \& Adolescent Psychiatry, 17(7), 414-423.

Fellinger, J., Holzinger, D., Sattel, H., Laucht, M., \& Goldberg, D. (2009). Correlates of mental health disorders among children with hearing impairments. Developmental Medicine \& Child Neurology, 51(8), 635-641.

Field, A. (2013). Discovering Statistics using IBM SPSS Statistics. Los Angeles: Sage. 
Fitzpatrick, E. M., Crawford, L., Ni, A., \& Durieux-Smith, A. (2011). A descriptive analysis of language and speech skills in 4 - to 5 year-old children with hearing loss. Ear \& Hearing, 32, 605-616.

Fitzpatrick, E. M., Olds, J., Gaboury, I., McCrae, R., Schramm, D., \& Durieux-Smith, A. (2012). Comparison of outcomes in children with hearing aids and cochlear implants. Cochlear Implants International, 13(1), 5-15.

Fonagy, P., Gergely, G., \& Target, M. (2007). The parent-infant dyad and the construction of the subjective self. Journal of Child Psychology and Psychiatry, 48(3/4), 288-328.

Forli, F., Arslan, E., Bellelli, S., Burdo, S., Mancini, P., Martini, A., . . . Berrettini, S. (2011). Systematic review of the literature on the clinical effectiveness of the cochlear implant procedure in paediatric patients. Acta Otorhinolaryngologica Italica, 31, 281-298.

Fortnum, H. M., Marshall, D. H., \& Summerfield, A. (2002). Epidemiology of the UK population of hearing-impaired children, including characteristics of those with and without cochlear implants - audiology, aetiology, comorbidity and affluence. International Journal of Audiology, 41, 170-179.

Fulcher, A., Purcell, A. A., Baker, E., \& Munro, N. (2012). Listen up: Children with early identified hearing loss achive age-appropriate speech/language outcomes by 3 yearsof-age. International Journal of Pediatric Otorhinolaryngology, 76, 1785-1794.

Gatehouse, S., \& Noble, W. (2004). The Speech, Spatial and Qualities of Hearing Scale (SSQ). International Journal of Audiology, 43, 85-99.

Geary, D. C. (2011). Consequences, Characteristics, and Causes of Mathematical Learning Disabilities and Persistent Low Achievement in Mathematics. Journal of Developmental and Behavioral Pediatrics, 32(3), 250-263.

Geers, A. E. (2002). Factors Affecting the Development of Speech, Language, and Literacy in Children With Early Cochlear Implantation. Language, Speech \& Hearing Services in the Schools, 33(3), 172-183. 
Geers, A. E., Brenner, C., \& Davidson, L. (2003). Factors associated with development of speech perception skills in children implanted by age five. Ear \& Hearing, 2(1), 2435.

Geers, A. E., Mitchell, C. M., Warner-Czyz, A., Wang, N.-Y., Eisenberg, L. S., \& DCaCI Investigative Team. (2017). Early Sign Language Exposure and Cochlear Imlantation Benefits. Pediatrics, 140(1), 1-9.

Geers, A. E., Moog, J. S., Biedenstein, J., Brenner, C., \& Hayes, H. (2009). Spoken Language Scores of Children Using Cochlear Implants Compared to Hearing Age-Mates at School Entry. Journal of Deaf Studies \& Deaf Education, 14(3).

Geers, A. E., Pisoni, D. B., \& Brenner, C. (2013). Complex Working Memory Span in Cochlear Implanted and Normal Hearing Teenagers. Otol Neurotol, 34(3), 396-401.

Goldstein, M. H., Schwade, J. A., \& Bornstein, M. H. (2009). The value of vocalizing: Fivemonth-old infants associate their own noncry vocalizations with responses from caregivers. Child Development, 80(3), 636-644.

Graven, S. N., \& Browne, J. V. (2008). Auditory development in the fetus and infant. Newborn and Infant Nursing Reviews, 8(4), 187-193.

Gustafson, S. J., Davis, H., Hornsby, B. W., \& Bess, F. H. (2015). Factors influencing hearing aid use in the classroom: A pilot study. American Journal of Audiology, 24, 563-568.

Halliday, L. F., Tuomainen, O., \& Rosen, S. (2016). Language development and impairment in children with mild to moderate sensorineural hearing loss. Journal of Speech, Language, and Hearing Research, 60, 1551-1567.

Hammer, A., \& Coene, M. (2016). Finite Verb Morphology in the Spontaneous Speech of Dutch-Speaking Children With Hearing Loss. Ear \& Hearing, 37(1), 64-72.

Hammer, A., Coene, M., Rooryck, J., \& Govaerts, P. J. (2014). The production of Dutch finite verb morphology: A comparison between hearing-impaired CI children and specific language impaired children. Lingua, 139, 68-79.

Haukedal, C. L., Lyxell, B., \& Wie, O. B. (2019). Health-Related Quality of Life With Cochlear Implants: The Children's Perspective. Ear \& Hearing. 
Haukedal, C. L., Torkildsen, J. V. K., Lyxell, B., \& Wie, O. B. (2018). Parents' perception of health-related quality of life in children with cochlear implants: the impact of language skills and hearing. Journal of Speech, Language, and Hearing Research, 61(8), 20842098.

Hays, R. D., \& Reeve, B. B. (2008). Measurement and modeling of health-related quality of life. In K. Heggenhougen \& S. Quah (Eds.), International Encyclopedia of Public Health (Vol. 4, pp. 241-252). San Diego: Academic Press.

Helsedirektoratet. (2017). Screening av hørsel hos nyfødte. Nasjonal faglig rettnigslinje.: Helsedirektoratet Retrieved from https://www.helsedirektoratet.no/retningslinjer/screening-av-horsel-hos-nyfodte.

Hendar, O. (2012). Elever med hørselshemming i skolen. En kartleggingsundersøkelse om lceringsutbytte: : Statped. Skådalen kompetansesenter.

Hepper, P. G., \& Shahidullah, B. S. (1994). Development of fetal hearing. Archives of Disease in Childhood, 71, 81-87.

Hintermair, M. (2011). Health-related quality of life and classroom participation of deaf and hard-of-hearing students in general schools. Journal of Deaf Studies \& Deaf Education, 16(2), 254-271.

Hornsby, B. W., Gustafson, S. J., Lancaster, H., Cho, S.-J., Camarata, S., \& Bess, F. H. (2017). Subjective Fatigue in Children With Hearing Loss Assessed Using Self- and Parent-Proxy Report. American Journal of Audiology, 26, 393-407.

Hornsby, B. W., Werfel, K., Camarata, S., \& Bess, F. H. (2014). Subjective fatigue in children with hearing loss: Some preliminary findings. American Journal of Audiology, 23(1), 129-134.

Huber, M. (2005). Health-related quality of life of Austrian children and adolescents with cochlear implants. International Journal of Pediatric Otorhinolaryngology, 69(8), 1089-1101.

Huber, M., Burger, T., Illg, A., Kunze, S., Giourgas, A., Braun, L., . . Keilmann, A. (2015). Mental health problems in adolescents with cochlear implants: Peer problems persist 
after controlling for additional handicaps. Frontiers in Psychology Vol 6 Jul 2015, ArtID 953, 6.

Huber, M., \& Havas, C. (2019). Restricted Speech Recognition in Noise and Quality of Life of Hearing-Impaired Children and Adolescents With Cochlear Implants - Need for Studies Addressing This Topic With Valid Pediatric Quality of Life Instruments. Frontiers in Psychology, 10, 1-9.

Huber, M., Pletzer, B., Giourgas, A., Nickisch, A., Kunze, S., \& Illg, A. (2015). Schooling Relates to Mental Health Problems in Adolecents with Cochlear Implants- Mediation by Hearing and Family Variables. Frontiers in Psychology, 6.

Janicke, D. M., Finney, J. W., \& Riley, A. W. (2001). Children's Health Care Use: A Prospective Investigation of Factors Related to Care-Seeking. Medical Care, 39(9), 990-1001.

Joint Committe on Infant Hearing. (2019). Year 2019 Position Statement: Principles and Guidelines for Early Hearing Detection and Intervention Programs. The Journal of Early Hearing Detection and Intervention, 4(2), 1-44.

Joint Committee on Infant Hearing. (1994). Joint committee on infant hearing 1994 position statement. American Academy of Pediatrics.

Joint Committee on Infant Hearing. (2007). Year 2007 position statement: Principles and guidelines for early hearing detection and intervention programs. Pediatrics, 120(4).

Jusczyk, P. W. (1999). How infants begin to extract words from speech. Review. Trends in Cognitive Sciences, 3(9).

Karimi, M., \& Brazier, J. (2016). Health, Health-Related Quality of Life, and Quality of Life: What is the Difference? PharmacoEconomics, 34, 645-649.

Karltorp, E., Eklöf, M., Östlund, E., Asp, F., Tideholm, B., \& Löfkvist, U. (2019). Cochlear implants before nine months of age led to more natural spoken language development without increased surgical risks. Acta Paediatrica, 00, 1-10. 
Keilmann, A., Limberger, A., \& Mann, W. J. (2007). Psychological and physical well-being in hearing-impaired children. International Journal of Pediatric Otorhinolaryngology, 71(11), 1747-1752.

Ketelaar, L., Rieffe, C., Wiefferink, C. H., \& Frijns, J. H. (2013). Social competence and empathy in young children with cochlear implants and with normal hearing. Laryngoscope, 123(2), 518-523.

Kirman, A., \& Sari, H. Y. (2013). Health status of hearing-impaired children and adolescents. International Journal of Nursing Practice, 19(3), 233-240.

Koehlinger, K. M., Van Horne, A. J., \& Moeller, M. P. (2013). Grammatical outcomes of 3and 6-year-old children who are hard of hearing. Journal of Speech Language \& Hearing Research, 56(5), 1701-1714.

Korver, A. M., Konings, S., Dekker, F. W., Beers, M., Wever, C. C., Frijns, J. H., . . Group, D. C. S. (2010). Newborn hearing screening vs later hearing screening and developmental outcomes in children with permanent childhood hearing impairment. JAMA: Journal of the American Medical Association, 304(15), 1701-1708.

Kral, A., \& Sharma, A. (2012). Developmental Neuroplasricity After Cochlear Implantation. Trends in Neuroscience, 35(2), 111-122.

Kuhl, P. K., Conboy, B. T., Padden, D., Nelson, T., \& Pruitt, J. (2005). Early Speech Perception and Later Language Development: Implications for the "Critical Period". Language Learning and Development, 1(3-4), 237-264.

Kvaerner, K. J., \& Arnesen, A. R. (1994). Hearing Impairment in Oslo Born Children 198991: Incidence, Etiology and Diagnostic Delay. Scandinavian Audiology, 23(4), 233239.

Lane, H. (1993). The mask of benevolence: disabling the deaf community. New York: Vintage Books.

Lane, H. (2005). Ethnicity, Ethics, and the Deaf-World. Journal of Deaf Studies \& Deaf Education, 10(3), 291-310.

Larsen, P. (2005). Lørdagsdikt: første volum. Oslo: Lille måne. 
Laugen, N. J., Jacobsen, K. H., Rieffe, C., \& Wichstrøm, L. (2016). Predictors of psychosocial outcomes in hard-of-hearing preschool children. Journal of Deaf Studies \& Deaf Education, 259-267.

Leigh, J., Dettman, S., Dowell, R., \& Briggs, R. (2013). Communication Development in Children Who Receive a Cochlear Implant by 12 Months of Age. 34, 443-450.

Leonard, L. B. (2014). Children with Specific Language Impairment (2nd ed.). Cambridge, Mass: MIT Press.

Lin, F. R., \& Niparko, J. K. (2006). Measuring health-related quality of life after pediatric cochlear implantation: a systematic review. International Journal of Pediatric Otorhinolaryngology, 70(10), 1695-1706.

Loy, B., Warner-Czyz, A. D., Tong, L., Tobey, E. A., \& Roland, P. S. (2010). The children speak: an examination of the quality of life of pediatric cochlear implant users. Otolaryngology - Head \& Neck Surgery, 142(2), 247-253.

Lund, E. (2015). Vocabulary knowledge of children with cochlear implants: A meta-analysis. Journal of Deaf Studies \& Deaf Education, 1-15.

Lyxell, B., Sahlèn, B., Wass, M., Ibertsson, T., Larsby, B., Hällgren, M., \& Mäki-Torkko, E. (2008). Cognitive development in children with cochlear implants: Relations to reading and communications. International Journal of Audiology, 47, 47-52.

Lyxell, B., Wass, M., Sahlèn, B., Uhlen, I., Samuelsson, C., Asker-Àrnason, L., . . Hällgren, M. (2011). Development of cognitive and reading skills in deaf children with CIs. Cochlear Implants International, 12(1), 98-100.

Mäki-Torkko, E., Lindholm, P. K., Väryrynen, M. R. H., Leisti, J. T., \& Sorri, M. (1998). Epidemiology of Moderate to Profound Childhood Hearing Impairments in Northern Finland. Any Changes in Ten Years? Scandinavian Audiology, 27(2), 95-103.

Maldonado, G., \& Greenland, S. (1993). Simulation Study of Confounder-Selection Strategies. American Journal of Epidemiology, 138(11), 923-936. 
Manrique, M., Cervera-Paz, F. J., Huarte, A., \& Molina, M. (2004). Prospective Long-term Auditory Results of Cochlear Implantation in Prelinguistically Deafened Children: The Importance of Early Implantation. Acta Oto-Laryngologica, 55-63.

Martikainen, P., Bartley, M., \& Lahelma, E. (2002). Psychosocial determinants of health in social epidemiology. International Epidemiological Association, 32, 1091-1093.

Matza, L. S., Swensen, A. R., Flood, E. M., Secnik, K., \& Leidy, N. K. (2004). Assessment of health-related quality of life in children: A review of conceptual, methodological, and regulatory issues. Value in Health, 7. doi:10.1111/j.1524-4733.2004.71273.x

Mayer, C., \& Trezek, B. J. (2018). Literacy Outcomes in Deaf Students with Cochlear Implants: Current State of the Knowledge. Journal of Deaf Studies \& Deaf Education, 23(1), 1-16.

Mehra, S., Eavey, R. D., \& Keamy, D. G. (2009). The epidemiology of hearing impairment in the United States: Newborns, children, and adolescents. Otolaryngology - Head \& Neck Surgery, 140, 461-472.

Meserole, R. L., Carson, C. M., Riley, A. W., Wang, N.-Y., Quittner, A. L., Eisenberg, L. S., . . Niparko, J. K. (2014). Assessment of health-related quality of life 6 years after childhood cochlear implantation. Quality of Life Research: An International Journal of Quality of Life Aspects of Treatment, Care \& Rehabilitation, 23(2), 721-733.

Michalos, A. C. (2015). Ancient Views on the Quality of Life. In.

Miyamoto, R. T., Svirsky, M. A., Kirk, K. I., \& Sehgal, S. T. (1999). Communication Skills in Pediatric Cochlear Implant Recipients. Acta Oto-Laryngologica, 119(2), 219-224.

Monzani, D., Galeazzi, G. M., Genovese, E., Marrara, A., \& Martini, A. (2008). Psychological profile and social behaviourof working adults with mild or moderate hearing loss. Acta Otorhinolaryngologica Italica, 28, 61-66.

Moon, C., Cooper, R. P., \& Fifer, W. P. (1993). Two-Day-Olds Prefer Their Native language. Infant behavior and development, 16, 495-500. 
Morettin, M., Santos, M. J., Stefanini, M. R., Antonio Fde, L., Bevilacqua, M. C., \& Cardoso, M. R. (2013). Measures of quality of life in children with cochlear implant: systematic review. Revista Brasileira de Otorrinolaringologia, 79(3), 375-381.

Moriyama, I. M. (1968). Problems in the measurement of health status. In E. B. Sheldon \& W. E. Moore (Eds.), Indicators of social change (pp. 573-600). New York: Russell Sage Foundation.

Most, T., Shina-August, E., \& Meilijson, S. (2010). Pragmatic abilities of children with hearing loss using cochlear implants or hearing aids compared to hearing children. Journal of Deaf Studies \& Deaf Education, 15(4), 422-437.

Myhrum, M., Tvete, O. E., Heldahl, M. G., Moen, I., \& Soli, S. D. (2016). The Norwegian hearing in noise test for children. Ear \& Hearing, 37, 80-92.

Netten, A. P., Rieffe, C., Soede, W., Dirks, E., Korver, A. M. H., Konings, S., . . group, D. C. s. (2017). Can You Hear What I Think? Theory of Mind in Young Children With Moderate Hearing Loss. Ear \& Hearing, 38(5), 588-597.

Nicholson, R. (1975). Should the patient be allowed to die? Journal of medical ethics, 1, 5-9.

Nimensivu, R., Roine, R. P., Sintonen, H., \& Kentala, E. (2018). Health-related quality of life in hearing-impaired adolescents and children. Acta Oto-Laryngologica, 138(7), 652658.

Nittrouer, S., Caldwell-Tarr, A., \& Lowenstein, J. H. (2013). Working memory in children with cochlear implants: Problems are in storage, not processing. International Journal of Pediatric Otorhinolaryngology, 77, 1886-1898.

Nittrouer, S., Muir, M., Teietgens, K., Moberly, A. C., \& Lowenstein, J. H. (2018). Development of Phonological, Lexical, and Syntactic Abilities in Children With Cochlear Implants Across the Elementary Grades. Journal of Speech, Language, and Hearing Research, 61, 2561-2577.

Norbury, C. F. (2019). Individual differences in language acquisition. In J. Horst \& J. V. K. Torkildsen (Eds.), International Handbook of Language Acquisition. New York, NY.: Routledge. 
Nordenfelt, L. (1991). Livskvalitet och hälsa-teori och kritik. Linköping: Instutionen för hälsa och samhälle. Linköpings universitet.

Oller, D. K. (2000). The emergence of the speech capacity. Mahwah, N.J.: Lawrence Erlbaum Associates.

Oller, D. K., Eilers, R. E., Neal, A. R., \& Cobo-Lewis, A. B. (1998). Late onset canonical babbling: A possible early marker of abnormal development. American Journal on Mental Retardation, 103(3), 249-263.

Øygarden, J. (2009). Norwegian Speech Audiometry (PhD thesis). Norwegian University of Science and Technology, Norway,

Percy-Smith, L., Caye-Thomasen, P., Breinegaard, N., \& Jensen, J. H. (2010). Parental mode of communication is essential for speech and language outcomes in cochlear implanted children. Acta Oto-Laryngologica, 130, 708-715.

Percy-Smith, L., Jensen, J. H., Cayé-Thomasen, P., Thomsen, J., Gudman, M., \& Lopez, A. G. (2008). Factors that affect the social well-being of children with cochlear implants. Cochlear Implants International, 9(4), 199-214.

Perez-Mora, R., Lassaletta, L., Castro, A., Herran, B., San-Roman-Montero, J., Valiente, E., \& Gavilan, J. (2012). Quality of life in hearing-impaired children with bilateral hearing devices. $B-E N T, 8(4), 251-255$.

Peterson, C. C. (2004). Theory-of-mind development in oral deaf children with cochlear implants or conventional hearing aids. Journal of Child Psychology and Psychiatry, 45(6), 1096-1106.

Peterson, N. R., Pisoni, D. B., \& Miyamoto, R. T. (2010). Cochlear implants and spoken language processing abilities: Review and assessment of the literature. Restorative Neurology and Neuroscience, 1(28), 237-250.

Pisoni, D. B., Kronenberger, W. G., Harris, M., \& Moberly, A. C. (2017). Three challenges for future research on cochlear implants. World Journal of OtorhinolaryngologyHead and Neck Surgery, 3, 240-254. 
Post, M. W. M. (2014). Definitions of Quality of Life: What Has Happened and How to Move On. Topics in Spinal Cord Injury Rehabilitation, 20(3), 167-180.

Rachakonda, T., Jeffe, D. B., Shin, J. J., Mankarious, L., Fanning, R. J., Lesperance, M. M., \& Lieu, J. E. (2014). Validity, discriminative ability, and reliability of the hearingrelated quality of life questionnaire for adolescents. Laryngoscope, 124(2), 570-578.

Raven, J. (2004). Coloured progressive matrices and crichton vocabulary scale. Manual. London: Pearson.

Raven, J. (2008). Standard progressive matrices - plus version and mill hill vocabulary scale. Manual. London: Pearson.

Razafimahefa-Raoelina, T., Farinetti, A., Nicollas, R., Triglia, J.-M., Roman, S., \& Anderson, L. (2016). Self-and parental assessment of quality of life in child cochlear implant bearers. European annals of otorhinolaryngology, head and neck diseases, 133(1), 3135.

Regionale komiteer for medisinsk og helsefaglig forskningsetikk. (n.d.). Forskningsprosjekt: Cochleaimplantatert som barn. Retrieved from https://helseforskning.etikkom.no/prosjekterirek/prosjektregister/prosjekt?p_document _id $=316870 \& p \_$parent $\_$id $=330968 \& \_$ikbLanguageCode $=n$

Reindal, S. M. (2009). International Classification of Functioning, Disability and Health. European Journal of Special Needs Education, 24(2), 155-168.

Reinfjell, T., Diseth, T. H., Veenstra, M., \& Vikan, A. (2006). Measuring health-related quality of life in young adolescents: Reliability and validity in the Norwegian version of the Pediatric Quality of Life InventoryTM 4.0 (PedsQL) generic core scales. Health and Quality of Life Outcomes, 4(61).

Roland, L., Fischer, C., Tran, K., Rachakonda, T., Kallogjeri, D., \& Lieu, J. E. (2016). Quality of life in children with hearing impairment: Systematic review and metaanalysis. Otolaryngology - Head \& Neck Surgery, 155(2), 208-219.

Roth, T. N., Hanebuth, D., \& Probst, R. (2011). Prevalence of age-related hearing loss in Europe: a review. European Archives of Oto-Rhino-Laryngology, 268(8), 1101-1107. 
Ruta, D., Camfield, L., \& Donaldson, C. (2007). Sen and the art of quality of life maintenance: Towards a general theory of quality of life and its causation. The Journal of Socio-Economics, 36, 397-423.

Sach, T. H., \& Barton, G. R. (2007). Interpreting parental proxy reports of (health-related) quality of life for children with unilateral cochlear implants. International Journal of Pediatric Otorhinolaryngology, 71(3), 435-445.

Saxena, S., \& Orley, J. (1997). Quality of life assessment: the World Health Organization perspective. Eur Psychiatry, 12, 263-266.

Semel, E., Wiig, E. H., \& Secord, W. A. (2003). Clinical evaluation of language fundamentals. 4th edition. San Antonio, TX: Harcourt Assessment.

Service for Sensitive Data. (2019). About TSD. Retrieved from https://www.uio.no/english/services/it/research/sensitive-data/about/index.html

Shadish, W. R., Cook, T. D., \& Campbell, D. T. (2002). Experimental and quasiexperimental designs for generalized causal inference. Boston: Houghton Mifflin.

Sharma, A., \& Campbell, J. (2011). A sensitive period for cochlear implantation in deaf children. The Journal of Maternal-Fetal \& Neonatal Medicine, 24(1), 151-153.

Sharma, A., Campbell, J., \& Cardon, G. (2015). Developmental and cross-modal plasticity in deafness: Evidence from the P1 and N1 event related potentials in cochlear implanted children. International Journal of Pstchophysiology, 95(2), 135-144.

Sharma, A., Dorman, M. F., \& Spahr, A. J. (2002). A Sensitive Period for the Development of the Central Auditory System in Children with Cochlear Implants: Implications for Age of Implantation. Ear \& Hearing, 23, 532-539.

Sininger, Y. S., Grimes, A., \& Christensen, E. (2010). Auditory development in early amplified children: factors influencing auditory-based communication outcomes in children with hearing loss. Ear \& Hearing, 31(2), 166-185.

Spitzer, W. O. (1987). State of science 1986: Quality of life and functional status as target variables for research. Journal of Chronic Diseases, 40(6), 465-471. 
Stach, B. A. (2010). Clinical Audiology. An Introduction. (2 ed.). New York: Delmar Centage Learning.

Statistics Norway. (2019). Fødte. Retrieved from https://www.ssb.no/befolkning/statistikker/fodte

Statlig spesialpedagogisk tjeneste. Tjenester innen hørsel. Retrieved from https://www.statped.no/tjenester/tjenester-pr-fagomrade/tjenester-innen-horsel/

Statlig spesialpedagogisk tjeneste. (2018, 25.09.18). Strakstilbud ved hørselstap. Retrieved from https://www.statped.no/tjenester/strakstilbud/strakstilbud-ved-horselstap/

Stevenson, J., Kreppner, J., Pimperton, H., Worsfold, S., \& Colin, K. (2015). Emotional and behavioural difficulties in children and adolescents with hearing impairment: a systematic review and meta-analysis. Eur Child Adolesc Psychiatry, 24, 477-496.

Stevenson, J., McCann, D., Watkin, P., Worsfold, S., Kennedy, C., \& Hearing Outcomes Study Team. (2010). The relationship between language development and behaviour problems in children with hearing loss. Child Psychology and Psychiatry, 77-83.

Summerfield, A., Lovett, R. E., Bellenger, H., \& Batten, G. (2010). Estimates of the costeffectiveness of pediatric bilateral cochlear implantation. Ear \& Hearing, 31(5), 611624.

Sundqvist, A., Lyxell, B., Jonsson, R., \& Heimann, M. (2014). Understanding minds: early cochlear implantation and the development of theory of mind in children with profound hearing impairment. International Journal of Pediatric Otorhinolaryngology, 78(3), 537-543.

Svirsky, M. A., Teoh, S.-W., \& Neuburger, H. (2004). Development of Language and Speech Perception in Congenitally, Profoundly Deaf Children as a Function of Age at Cochlear Implantation. Audiology \& Neuro-Otology, 9, 224-233.

Tetzchner, S. v. (2001). Utviklingspsykologi. Oslo: Gyldendal Norsk Forlag.

The WHOQOL Group. (1995). The World Health Organization Quality of Life Assessment (WHOQOL): Position Paper from the World Health Organization. Soc Sci Med, 41(10), 1403-1409. 
Theunissen, S. C., Rieffe, C., Kouwenberg, M., Soede, W., Briaire, J. J., \& Frijns, J. H. (2011). Depression in hearing-impaired children. International Journal of Pediatric Otorhinolaryngology, 75(10), 1313-1317.

Theunissen, S. C., Rieffe, C., Netten, A. P., Briaire, J. J., Soede, W., Schoones, J. W., \& Frijns, J. H. (2014). Psychopathology and its risk and protective factors in hearingimpaired children and adolescents. A systematic review. JAMA, 168(2), 170-177.

Theunissen, S. C., Rieffe, C., Soede, W., Briaire, J. J., Ketelaar, L., Kouwenberg, M., \& Frijns, J. H. (2015). Symptoms of psychopathology in hearing-impaired children. Ear \& Hearing, 36(4), e190-198.

Tomasello, M. (1999). The human adaptation for culture. Annual reviews of anthroplogy, 28, 509-529.

Tomblin, B., Harrison, M., Ambrose, S. E., Walker, E., Oleson, J. J., \& Moeller, M. P. (2015). Language outcomes in young children with mild to severe hearing loss. Ear \& Hearing, 36, 76-91.

Torrance, G. W. (1987). Utility approach to measuring health- related quality of life. Journal of Chronic Diseases, 40(6), 593-600.

Umansky, A. M., Jeffe, D. B., \& Lieu, J. E. (2011). The HEAR-QL: Quality of Life questionnaire for children with hearing loss. Journal of the American Academy of Audiology, 22(10), 644-653.

Utdanningsdirektoratet. (2009). Veileder for opplaering av barn og unge med hørselshemming.

Varni, J. W., Burwinkle, T. M., Seid, M., \& Skarr, D. (2003). The PedsQL 4.0 as a pediatric population health measure: feasibility, reliability, and validity. Ambulatory Pediatrics, 3(6), 329-341.

Varni, J. W., Limbers, C. A., \& Burwinkle, T. M. (2007). Parent proxy-report of their children's health-related quality of life: an analysis of 13,878 parents' reliability and validity across age subgroups using the PedsQL тм 4.0 Generic Core Scales. Health \& Quality of Life Outcomes, 5(2). 
Varni, J. W., Seid, M., \& Kurtin, P. S. (2001). PedsQLTM 4.0: Reliability and validity of the pediatric quality of life inventory ${ }^{\mathrm{TM}}$ version 4.0 generic core scales in healthy and patient populations. Medical Care, 8(39), 800-812.

Vihman, M. (2019). Advances in early speech production. Interactions with maturation, perception and learning. In J. Horst \& J. V. K. Torkildsen (Eds.), International Handbook of Language Acquisition. New York, NY.: Routledge.

Wake, M., Hughes, E. K., Poulakis, Z., \& Collins, C. M. (2004). Parent-reported healthrelated quality of life in children with congenital hearing loss: a population study. Ambulatory Pediatrics, 4(5), 411-417.

Wake, M., Hughes, E. K., Poulakis, Z., Collins, C. M., \& Rickards, F. W. (2004). Outcomes of children with mild-profound congenital hearing loss at 7 to 8 years: a population study. Ear \& Hearing, 25(1), 1-8.

Wake, M., \& Poulakis, Z. (2004). Slight and mild hearing loss in primary school children. Journal of Paediatrics and Child Health, 40(1-2), 11-13.

Walker, E., Holte, L., McCreery, R. W., Spratford, M., Page, T., \& Moeller, M. P. (2015). The influence of hearing aid use on outcomes of children with mild hearing loss. Journal of Speech Language \& Hearing Research, 58(5), 1611-1625.

Walker, E., Spratford, M., Moeller, M. P., Oleson, J. J., Ou, H., Roush, P., \& Jacobs, S. (2013). Predictors of hearing aid use time in children with mild-severe hearing loss. Language, Speech \& Hearing Services in the Schools, 44(1), 73-88.

Warner-Czyz, A. D., Loy, B., Roland, P. S., Tong, L., \& Tobey, E. A. (2009). Parent versus child assessment of quality of life in children using cochlear implants. International Journal of Pediatric Otorhinolaryngology, 73(10), 1423-1429.

Wass, M. (2009). Cognition and Reading Ability. (Ph.d.), Linköping University, Linköping.

Werker, J. F., \& Tees, R. C. (1984). Cross-language speech perception: Evidence for perceptual reorganization during the first year of life. Infant behavior and development, 7, 49-63. 
Wie, O. B. (2010). Language development in children after receiving bilateral cochlear implants between 5 and 18 months. International Journal of Pediatric Otorhinolaryngology, 74(11), 1258-1266.

Wie, O. B., Falkenberg, E.-S., Tvete, O., \& Tomblin, B. (2007). Children with a cochlear implant: Characteristics and determinants of speech recognition, speech-recognition growth rate, and speech production. International Journal of Audiology, 46, 232-243.

Wilson, B., Tucci, D. L., Merson, M. H., \& O’Donoghue, G. M. (2017). Global hearing health care: new findings and perspectives. Lancet, 390, 2503-2515.

Winiger, A. M., Alexander, J. M., \& Diefendorf, A. O. (2016). Minimal hearing loss: From a failure-based approach to evidence-based practice. American Journal of Audiology, $25,232-245$.

Wolk, S., \& Allen, T. E. (1984). A 5-year follow-up of reading-comprehension achievement of hearing-impaired students in special education programs. The Journal of Special Education, 18(2), 161-176.

Wong, C. L., Ching, T. Y. C., Cupples, L., Button, L., Leigh, G., Marnane, V., . . Martin, L. (2017). Psychosocial development in 5-year-old children with hearing loss using hearing aids or cochlear implants. Trends in Hearing, 21, 2331216517710373.

World Health Organization. (1948). Constitution of the world health organization basic document. Geneva, Switzerland: World Health Organization.

World Health Organization. (2007). International classification of functioning, disability and health : children \& youth version : ICF-CY.: WHO press.

Yew, S. G. K., \& O’Kearney, R. (2013). Emotional and behavioural outcomes later in childhood and adolescence for children with specific language impairments: metaanalyses of controlled prospective studies. The Journal of Child Psychology and Psychiatry, 54(5), 516-524.

Yoshinaga-Itano, C., Johnson, C. D., Carpenter, K., \& Brown, A. S. (2008). Outcomes of Children with Mild Bilateral Hearing Loss and Unilateral Hearing Loss. Seminars in Hearing, 29(2), 196-211. 
Yoshinaga-Itano, C., Sedey, A. L., Wiggin, M., \& Chung, W. (2017). Early hearing detection and vocabulary of children with hearing loss. Pediatrics, 140(2).

Zaidman-Zait, A., Curle, D., Jamieson, J. R., Chia, R., \& Kozak, F. K. (2017). Health-Related Quality of Life Among Young Children With Cochlear Implants and Developmental Disabilities. Ear \& Hearing.

Zhang, W., Hong, S., Takeuchi, D. T., \& Mossakowski, K. N. (2012). Limited English proficiency and psychological distress among Latinos and Asian Americans. Social Science \& Medicine, 75, 1006-1014. 



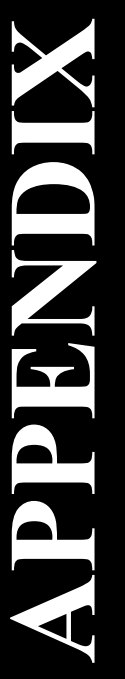





\title{
Forespørsel om deltakelse i forskningsprosjektet Cochleaimplantert som barn
}

\author{
Til foresatte til barn som har fått cochleaimplantat
}

\begin{abstract}
Bakgrunn og hensikt
Dette er et spørsmål til deg om du og ditt barn vil delta i en undersøkelse av taleoppfattelse, språkferdigheter og livskvalitet hos personer som har fått cochleaimplantat (CI) som barn. Vi henvender oss til deg fordi vi ønsker å inkludere alle som har fått cochleaimplantat ved Oslo Universitetssykehus (OUS) i perioden 1988 - 2012 og som var under 18 år da de fikk sitt første implantat. Ved å inkludere alle som har fătt CI i denne perioden, vil vi få kunnskap om den store variasjonen vi i dag ser blant de som har fått CI som barn. Studien gjøres på oppdrag fra Helsedirektoratet, som ønsker kunnskap om hvordan de som har fått CI som barn har det med hensyn til livskvalitet, muligheten til å høre og til å bruke hørselen i kommunikasjon. Hensikten med studien er å innhente kunnskap slik at en kan gi best mulig oppfølging til barn og unge voksne med cochleaimplantat. Studien gjennomføres i regi av CI-enheten ved OUS HF og i samarbeid med Universitetet i Oslo.
\end{abstract}

\section{Hva innebærer studien?}

Det å være deltaker i studien innebærer at du og ditt barn vil tilbringe noe mer tid ved OUS neste gang barnet skal til den årlige CI-kontrollen enn dere gjør ved en ordinær årskontroll. Hvor lang tid beror på individuelle forskjeller, men vi har beregnet at en kan besvare alle spørsmål og gjennomføre alle tester som inngår i undersøkelsen på samme dag som barnet er til kontroll.

Ved denne kontrollen vil barnet få kontrollert det som vanligvis kontrolleres ved årskontrollene. I den ekstra tiden som er satt av til studien vil vi undersøke hvordan barnet har nytte av CI i sin kommunikasjon og hvordan barnet bruker hørsel og språk. Det innebærer at vi inviterer barnet til å gjennomføre språktester og problemløsningstester ut fra barnets alder, evne og modenhet. Det legges særlig vekt på at barnet skal oppleve dette som en positiv opplevelse. Videre vil dere som foreldre få spørsmål om hvordan dere opplever at barnet påvirkes av å ha fått CI samt at dere besvarer spørsmål omkring barnets trivsel og velvære i dagliglivet. Dette innebærer å svare på spørreskjema som kan fylles ut mens dere er på sykehuset, enten i samarbeid med oss som gjennomfører undersøkelsen eller selvstendig.

Om du ikke tidligere og ved ordinære kontroller har fått tilbud om å få undersøkt årsaken til barnets hørselstap, vil du i forbindelse med denne undersøkelsen få tilbud om å undersøke om hørselstapet skyldes noen av de mest kjente årsakene til hørselstap. Det vil i den forbindelse tas blodprøve av barnet. Barnet får da et plaster med bedøvelse som gjør at selve stikket ikke gir smerte. Blodprøven undersøkes for å finne om hørselshemmingen kan skyldes infeksjonsrelaterte årsaker samt at det gjøres en genetisk undersøkelse av blodet for å finne om hørselstapet skyldes Pendreds eller Jervell og Lange Nielsen syndrom. Finner vi at hørselstapet skyldes genetiske årsaker, vil du få tilbud om genetisk rådgivning på avdeling for medisinsk genetikk ved Rikshospitalet. Studien ber om tillatelse til å bruke informasjon som ligger i barnets pasientjournal ved OUS og som er relevant til kartleggingen av 
hørsel, språk og årsak til hørselstap. Dersom ditt barn også deltar i eller skal delta i

forskningsprosjektet «Oversikt over språklydforvekslinger for voksne og barn med cochleaimplantat», ber vi om å kunne bruke noen av testresultatene fra dette forskningsprosjektet, samt at noen av testresultatene våre også kan brukes i dette forskningsprosjektet.

\section{Mulige fordeler og ulemper}

Deltagelse i studien går over en dag, og gjennomføres den dagen barnet er innkalt til CI-kontroll. Fordelen ved å delta i studien er at barnet får en grundigere undersøkelse enn en ellers ville fått. Økt kunnskap om hvordan barnet ditt fungerer språklig kan være nyttig og en hjelp til hvordan du selv kan bidra til barnets språkutvikling. Slik kunnskap kan også være nyttig i møte med fagpersoner som har ansvar for at barnet får tilstrekkelig oppfølging i barnehage og skole. Ulempen er at CI-kontrollen tar lengre tid enn den vanligvis gjør. Du må regne med at det kan ta inntil fire timer lengre enn en vanlig kontroll.

\section{Hva skjer med prøvene og informasjonen om barnet?}

Informasjonen som registreres om barnet skal kun brukes slik som beskrevet $\mathrm{i}$ hensikten med studien. Det vil si at resultatene vil analyseres og presenteres for Helsedirektoratet, for fagpersoner i hørselsomsorgen i Norge og internasjonalt. Alle opplysningene og prøvene vil bli behandlet uten navn og fødselsnummer eller andre direkte gjenkjennende opplysninger, bortsett fra blodprøven som du vil få svar på når den foreligger. En kode knytter deg til dine opplysninger og prøver gjennom en navneliste. Det er kun autorisert personell knyttet til prosjektet som har adgang til navnelisten og som kan finne tilbake til barnets identitet. Det vil ikke være mulig å identifisere deg i resultatene av studien når disse publiseres. All informasjon om barnet som innhentes i forbindelse med undersøkelsen og som ikke inngår i en vanlige CI-kontroll, vil slettes etter at undersøkelsen er ferdig publisert i 31.12.2023. I dette tidsrommet er det lagt inn mulighet for en oppfølgingsstudie. Hvis det blir bestemt å gjennomføre oppfølgingsstudien, vil vi kontakte deg igjen om fem år for å høre om du/ditt barn vil være med i den studien.

\section{Frivillig deltakelse}

Det er frivillig å delta i studien. Du kan når som helst og uten å oppgi noen grunn trekke ditt samtykke til å delta i studien. Dette vil ikke få konsekvenser for den videre behandling av ditt barn. Dersom du ønsker å delta, undertegner du samtykkeerklæringen på siste side. Om du nå sier ja til å delta, kan du senere trekke tilbake ditt samtykke uten at det påvirker din øvrige behandling. Dersom du senere ønsker å trekke deg eller har spørsmål til studien, kan du kontakte oss som arbeider med prosjekt ved Mariann Gjervik Heldahl 23071698, Marit Gismarvik 23076259/95769953.

Ytterligere informasjon om studien finnes i kapittel $\boldsymbol{A}$-utdypende forklaring av hva studien innebcerer.

Ytterligere informasjon om biobank, personvern og forsikring finnes i kapittel B - Personvern, biobank, økonomi og forsikring.

\section{Samtykkeerklæring følger etter kapittel B.}




\section{Kapittel A- utdypende forklaring av hva studien innebarer}

- Tidsskjema - hva skjer og når skjer det?

○ Studien vil gjennomføres i perioden 2013 til 2023. All informasjon som er planlagt innhentet, vil kunne gjennomføres samme dagen som barnet er til en av de vanlige oppfølgingskontrollene i løpet av denne perioden. Gjennomførelsen av hørsels- og språktestene kan også gjøres over to dager for deltakere som har behov for det.

\section{- Mulige fordeler}

○ En grundig gjennomgang av hørsel og språk kan være nyttig for barnet og for deg som foresatt. Ved at du som forelder er sammen med barnet under undersøkelsene av hørsel og språk, vil du få en mer detaljert kunnskap om barnets språk enn du vil få i en vanlig CIkontroll eller i samtale med barnet. Denne informasjonen kan være nyttig i din videre kommunikasjon med barnet, spesielt med tanke på områder der barnet trenger særlig språkstimulering. Ved forespørsel kan du få ettersendt barnets skårer på språktestene. Svar på hørselstest kan du få i løpet av konsultasjonen. Om det i løpet av studien oppdages forhold ved barnets hørsel og språk som krever veiledning og videre utredning, vil vi melde fra til deg og være behjelpelig med videre henvisning til aktuelle instanser.

\section{- Mulige ubehag/ulemper}

○ Det fører ikke til spesielle ubehag å delta i studien.

○ Om barnet er engstelige for å ta blodprøve, kan de få påført en salve slik at stikket ikke gjør vondt. Deltakere som ikke ønsker at det skal tas blodprøve, kan reservere seg for å ta blodprøver men fremdeles være med i studien.

- Spesielle interesser i studien

- I gruppen av barn som har fått CI har vi flere som har andre funksjonshemninger i tillegg til hørselshemning. Helsedirektoratet er spesielt interessert i å få kunnskap om disse barna og hvordan CI fungere for dem. For å få innhentet denne kunnskapen på en best mulig måte, kan det være aktuelt å gjennomføre besvarelsen av spørreskjema sammen med foresatte, samt intervju om det er forhold foresatte mener ikke kommer frem ved bruk av spørreskjema.

- Kartlegging av hørsel og språk

○ I studien vil vi kartlegge hørsel og talespråk. Hos brukere som ikke oppfatter tale slik at det er komfortabelt å bruke talespråk som hovedspråk, vil studien ved hjelp av spørreskjema kartlegge i hvilken grad de opplever nytte av den hørselen de har ved hjelp av CI.

- Kartlegging av årsak til hørselshemming

○ For de som tillater at vi innhenter blodprøve, vil vi undersøke om hørselstapet skyldes de mest kjente årsaker til hørselshemming. Det innebærer at vi undersøker infeksjonsrelaterte årsaker som toksoplasmose, cytomegalovirus (CMV) samt eventuelt rubella (røde hunder) og herpes simplex. Vi vil også gjøre genetiske prøver. En av disse er Connexin 26. Connexin 26 er den vanligste årsaken til hørselsnedsettelse i Norge og gir hørselsnedsettelse som eneste symptom. Hvis vi ser at det er medisinske grunner til videre undersøkelser, vil vi undersøke for Pendreds og Jervell og Lange Nielsen syndrom. Pendreds syndrom kan senere også gi svimmelhetsanfall og forandringer $\mathrm{i}$ skjoldbruskkjertelen. Jervell og Lange Nielsens syndrom kan i tillegg til hørselsnedsettelsen forårsake rytmeforstyrrelse i hjertet. Finner vi at hørselstapet skyldes noen av de siste to årsakene, vil du få tilbud om videre utredning og genetisk rådgivning på avdeling for medisinsk genetikk ved Rikshospitalet.

\section{- Undersøkelsene medfører ikke risiko og gir ingen bivirkninger.}


- Deltakere i studien har ansvar for å møte opp til avtalt tid og svare så samvittighetsfullt som mulig på spørreskjemaet.

- Deltakerne vil bli orientert så raskt som mulig dersom det blir gjort endringer i studien som kan påvirke ønsket om å delta. 


\section{Kapittel B - Personvern, biobank, økonomi og forsikring}

\section{Personvern}

Opplysninger som registreres om ditt barn er anonymisert, og barnets navn blir erstattet med en kode. Resultatene fra alle testene og svarene på spørreskjemaet vil bli registrert i en egen database. Dersom noen av testene er vanskelig å få gjennomført, men det finnes tilsvarende testresultater i barnets pasientjournal ved OUS, Rikshospitalet, vil en gå inn i journalen for å hente ut resultatene og bruke dem i studien. OUS ved administrerende direktør er databehandlingsansvarlig.

Dersom ditt barn også deltar i eller skal delta i forskningsprosjektet «Oversikt over språklydforvekslinger for voksne og barn med cochleaimplantat», ber vi om å kunne bruke noen av testresultatene fra dette forskningsprosjektet, samt at noen av testresultatene våre også kan brukes i dette forskningsprosjektet. Dette gjelder test av nonverbale evner, språk, tale og lesing (fra 3. klasse).

\section{Rett til innsyn og sletting av opplysninger om deg og sletting av prover}

Hvis du sier ja til å delta i studien, har du rett til å få innsyn i hvilke opplysninger som er registrert om ditt barn. Barn over 12 år kan imidlertid nekte foreldre innsyn i opplysningene de har avgitt. Du har videre rett til å få korrigert eventuelle feil i de opplysningene vi har registrert. Dersom du trekker deg fra studien, kan du kreve å få slettet innsamlede prøver og opplysninger, med mindre opplysningene allerede er inngått $i$ analyser eller brukt $i$ vitenskapelige publikasjoner.

\section{Økonomi}

Studien gjennomføres på oppdrag fra Helsedirektoratet og er finansiert av Helsedirektoratet, OUS og Universitetet i Oslo.

\section{Forsikring}

Det er ikke opprettet særskilte forsikringsordninger for denne undersøkelsen. De ordinære forsikringsordninger som gjelder for drift ved OUS gjelder.

\section{Informasjon om utfallet av studien}

Resultatet av studien vil være fritt tilgjengelig for deltakerne i form av publiserte artikler på norsk og engelsk og i foredrag til foreldre og fagfolk innen hørselsomsorgen. CI-enheten vil på oppfordring også oversende slike resultater til den enkelte deltaker. 


\section{Samtykke til deltakelse i studien}

(sett ring rundt svaret) Jeg er villig til sammen med mitt barn å delta i studien: Ja / Nei

(sett ring rundt svaret) Jeg er villig til at det tas blodprøve av mitt barn for genetiske undersøkelser: Ja / Nei

(Foresattes navn, dato)

(Foresattes navn, dato)

Jeg bekrefter å ha gitt informasjon om studien

(Signert, rolle i studien, dato) 


\title{
Request for participation in the research project Cochlear implanted as children
}

\author{
To guardians of children who have received cochlear implants
}

\begin{abstract}
Background and intention
This is request for you if you and your child would like to participate in a study of speech comprehension, language skills and quality of life in persons who have received cochlear implants as children. We are addressing you because we wish to include all who have received cochlear implants at Oslo University Hospital (OUS) during the period 1988-2012 and who were under the age of 18 when they received their first implant. By including everyone who received CI during this period, we will gain knowledge about the great variation we see today in those who have received CI as children. The study is commissioned by the Norwegian Directorate of Health, who want knowledge about how those who have received $\mathrm{CI}$ as children are doing with regards to quality of life, the possibilities of hearing and using their hearing to communicate. The intention of the study is to gather knowledge so as to give the best possible after-care to children and young adults with cochlear implants. The study is implemented and organised by the CI-unit at OUS-HF and in cooperation with the University of Oslo.
\end{abstract}

\section{What does the study involve?}

Participating in the study means that you and your child will spend a little more time at OUS the next time the child comes in for his/her annual CI-check-up than you do at an ordinary annual check-up. How much more time depends on individual differences, but we have calculated that all the questions can be answered and all the tests included in the examination can be implemented on the same day as the check-up.

At this check-up the child will get the same examinations as at the ordinary annual check-ups. In the extra time set aside for the study we will examine how the child makes use of his/her CI in communication and how the child uses hearing and language. That means that we invite the child to go through language tests and problem-solving tests adapted to the child's age, ability and maturity. We emphasise the importance of the child seeing this as a positive experience. Further on, you as parents will get questions about your experience of how the child is affected by having received CI, as well as answering questions about the child's happiness and well-being in day-to-day life. This means answering the questionnaire, which can be completed while you are at the hospital, either in cooperation with us who are doing the study, or on your own.

If you have not previously and at ordinary check-ups been offered to examine the cause of your child's hearing loss, you will, in connection with this check-up, be offered to examine whether the hearing loss is due to any of the most commonly known causes of hearing loss. In that connection, blood samples will be taken of the child. The child will get a local anesthetic patch which makes the blood test painless. The blood sample is examined to find out if the hearing impairment is due to infection related causes as well as genetic testing of the blood to find out whether the hearing loss is caused by Pendreds or Jervell and Lange Nilsen syndrome. If we find the hearing loss to be due to genetic causes, 
you will be offered genetic counseling at the department of medical genetics at Rikshospitalet. The study asks permission to use information from the child's patient journal at OUS which is relevant for the mapping of hearing, language and cause of hearing loss.

\section{Possible advantages and disadvantages}

Participation in the study spans over one day, and is done the same day as the child is called in for CIcheck-up. The advantage of participating in the study is that the child gets a more thorough examination than he/she would otherwise get. Increased knowledge of how your child is functioning linguistically can also be useful and help you contribute to the child's language development. Such information can also be useful in meeting professionals responsible for giving the child adequate care in day care and school. The disadvantage is that the CI check-up takes longer than it normally does. You have to be prepared to spend up to four more hours than at the normal check-up.

\section{What happens to the tests and the information about the child?}

The registered information about the child can only be used such as described in the intention of the study. That means the results will be analysed and presented to the Norwegian Directory of Health, to professionals in hearing care in Norway and internationally. All information and tests will be treated without name and national identity number or any other directly recognisable information, except the blood test to which you will get the answer when it is available. A code connects you to your information and tests through a name list. Only authorised personnel connected to this project have access to the name list and can look up the child's identity. It will not be possible to identify you in the results of the study when these are published. All information about the child which is collected in connection with the study and which is not part of a normal CI check-up, will be deleted after completion of the publishing of the study 31.12.2023. During this time span we have included possibilities of a follow-up study. If it is decided to implement the follow-up study, we will get in touch again to invite you/your child to participate in the study.

\section{Voluntary participation}

Participation in the study is voluntary. You can at any time and without giving reasons withdraw your consent to participating in the study. This will not have consequences for the further treatment of your child. If you wish to participate, sign the consent form on the final page. If at present you agree to participate, you can at a later point withdraw your consent without this affecting your other treatment. If, later, you wish to withdraw or have questions about the study, you can contact us who are working with the project, Mariann Gjervik Heldahl 23071698, Marit Gismarvik 23076259.

Further information about the study can be found in chapter $\mathbf{A}$-Further explanation of what the study involves.

Further information about biobank, data protection and insurance can be found in chapter BData protection, biobank, economy and insurance.

\section{Consent form follows chapter B.}




\section{Chapter A-further explanation of what the study involves}

- Time schedule - what will happen and when will it happen?

- The study will be done during the period 2013-2023. All planned data collection, will be done on the same day as the child comes in for one of the normal check-ups during this period. The hearing and language testing can also be done over the course of two days for participants for whom this is necessary.

\section{- Possible advantages}

- A thorough examination of hearing and language can be useful for the child and for you as a parent. By you, the parent, accompanying the child during the examinations of hearing and language, you will get more detailed knowledge of the child's language than you would at the normal CI check-up or in conversation with the child. This information can be useful in your further communication with the child, especially considering areas where the child needs special language stimulation. Upon request the child's scores on the language tests can be forwarded to you. You can get answers to the hearing tests during the consultation. If, during the study, circumstances are uncovered regarding the child's hearing and language that requires guidance and further examination, we will report this to you and be helpful in referring to the proper institutions.

\section{- Possible discomfort/disadvantages}

- Participating in the study does not lead to any special discomfort.

- If the child is worried about taking a blood test, we can apply a liniment so that the sting from the needle does not hurt. Participants who do not wish to have a blood test taken, can opt out of the blood tests, but still participate in the study.

\section{- Special interests in the study}

○ In the group of children who have received CI we have several children who have other disabilities in addition to hearing impairment. The Directorate of Health is especially interested in information about these children and how CI works for them. To collect this information in the best possible way it may be appropriate to answer the questionnaire with the parents, as well as an interview about whether there are conditions that were not uncovered by use of the questionnaire.

- Mapping of hearing and language

$\circ$ In the study we will be mapping hearing and speech. In users who do not perceive speech so that it is comfortable to use speech as the main language, the study will use questionnaires to help map to what extent they experience usefulness of the hearing they have thanks to CI.

\section{- Mapping of cause of hearing impairment}

$\circ$ For those who permit collection of a blood sample, we will examine whether the hearing loss is due to the most widely known causes of hearing impairment. This means that we will examine infection related causes such as toxoplasmosis, cytomegalovirus (CMV), as well as possibly rubella and herpes simplex. We will also do genetic tests. One of these is Connexin 26. Connexin 26 is the most common cause of hearing impairment in Norway and has hearing impairment as the only symptom. If we consider there to be medical reasons for further examinations, we will check for Pendred and Jervell and Lange Nielsen syndrome. Pendreds syndrome can later also give dizzy spells and changes in the thyroid. Jervell and Lange Nielsen syndrome can in addition to hearing impairment cause heart rhythm disturbances. If we find the hearing loss to be caused by any of the two latter 
causes, you will be offered further examination and genetic counselling at the department of medical genetics at Rikshospitalet.

- The examinations do not cause any risks or side effects.

- Participants in the study are responsible for showing up on scheduled time and answer the questionnaire as conscientiously as possible.

- Participants will be informed as soon as possible if changes are made in the study which might affect the willingness to participate. 


\section{Chapter B - Data security, biobank, economy and insurance}

\section{Data security}

Information registered about your child is made anonymous, and the child's name is replaced by a code. The results from all the tests and the answers from the questionnaire will be registered in a specific database. If it is difficult to go through with some of the tests, but there are equivalent test results in the child's patient journal at OUS, Rikshospitalet, we will go into the journal to collect the results and use them in the study. OUS, represented by the CEO, is responsible for the treatment of the data.

\section{Right of access and deletion of information about you and deletion of tests}

If you agree to participate in the study, you have the right of access to what information is registered about your child. Children over the age of 12, however, can refuse their parents' access to the information they have given. Further, you have the right to correct any mistakes in the information we have registered. If you withdraw from the study, you can demand for the collected tests and information to be deleted, unless the information has already been included in analyses or used in scientific publications.

\section{Economy}

The study is commissioned by the Norwegian Directory of Health and is financed by the Directory of Health, OUS and the University of Oslo.

\section{Insurance}

No special insurance scheme has been set up for this study. Ordinary insurance schemes for the operation of OUS apply.

\section{Information about the outcome of the study}

The results of the study will be freely available to the participants in the form of published articles in Norwegian and English and in lectures to parents and professionals within hearing care. The CI-unit will also, upon request, send such results to the individual participants. 


\section{Consent to participate in the study}

(please circle your answer)

(please circle your answer)
I am willing to participate in the study with my child: Yes/No

I am willing to have blood tests done on my child for genetic examinations: Yes/No

(Name of guardian, date)

(Name of guardian, date)

I confirm to have informed about the study

(Signature, role in the study, date) 